2019-02

\title{
What controls submarine channel development and the morphology of deltas entering deep-water fjords?
}

\author{
Gales, Jenny
}

http://hdl.handle.net/10026.1/12406

\subsection{2/esp.4515}

Earth Surface Processes and Landforms

Wiley

All content in PEARL is protected by copyright law. Author manuscripts are made available in accordance with publisher policies. Please cite only the published version using the details provided on the item record or document. In the absence of an open licence (e.g. Creative Commons), permissions for further reuse of content should be sought from the publisher or author. 


\section{What controls submarine channel development and the morphology of deltas entering deep-water fjords?}

Gales $\mathrm{J}^{1 *}$, Talling $\mathrm{PJ}^{2}$, Cartigny $\mathrm{MJB}^{2}$, Hughes Clarke $\mathrm{J}^{3}$, Lintern $\mathrm{G}^{4}$, Stacey $\mathrm{C}^{4}$ \& Clare $M A^{5}$.

1 University of Plymouth, Drake Circus, Plymouth, PL4 8AA, UK

2 University of Durham, Stockton Road, Durham, DH1 3LE, UK

3 Center for Coastal \& Ocean Mapping/Joint Hydrographic Center, Jere A. Chase Ocean Engineering Lab, 24 Colovos Road, Durham, New Hampshire 03824, USA

4 Natural Resources Canada's Geological Survey of Canada, Sidney, British

Columbia, Canada

5 National Oceanography Centre, University of Southampton Waterfront Campus, Southampton, SO143ZH, UK

${ }^{*}$ Corresponding author email: jenny.gales@plymouth.ac.uk

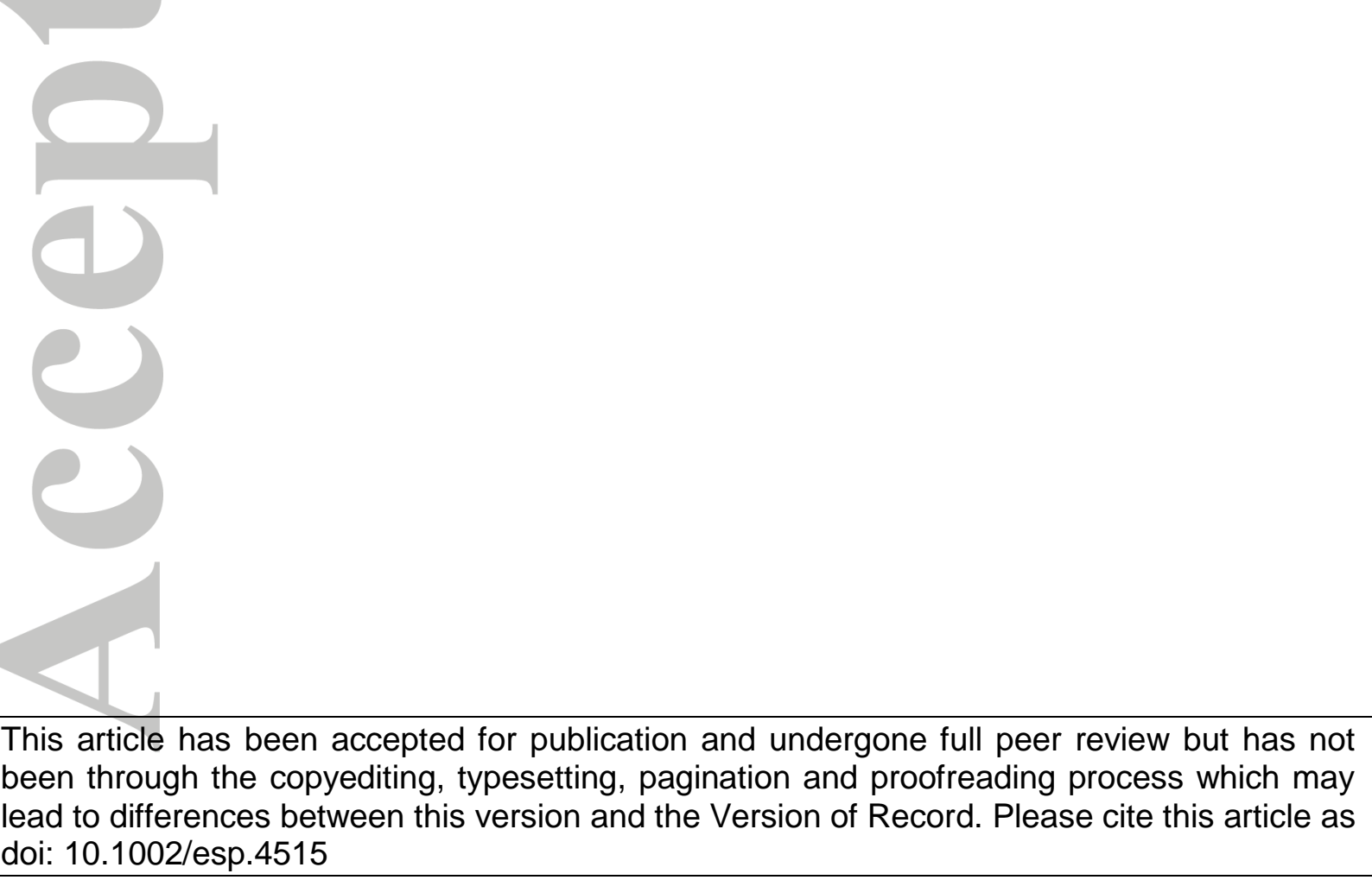




\section{Abstract}

River deltas and associated turbidity current systems produce some of the largest and most rapid sediment accumulations on our planet. These systems bury globally significant volumes of organic carbon and determine the runout distance of potentially hazardous sediment flows and the shape of their deposits. Here we seek to understand the main factors that determine the morphology of turbidity current systems linked to deltas in fjords, and why some locations have well developed submarine channels whilst others do not. Deltas and associated turbidity current systems are analysed initially in five fjord systems from British Columbia in Canada, and then more widely. This provides the basis for a general classification of delta and turbidity current system types, where rivers enter relatively deep (>200 m) water. Fjord-delta area is found to be strongly bimodal. Avalanching of coarse-grained bedload delivered by steep mountainous rivers produces small Gilbert-type fandeltas, whose steep gradient $\left(11^{\circ}-25^{\circ}\right)$ approaches the sediment's angle of repose. Bigger fjord-head deltas are associated with much larger and finer-grained rivers. These deltas have much lower gradients $\left(1.5^{\circ}-10^{\circ}\right)$ that decrease offshore in a near exponential fashion. The lengths of turbidity current channels are highly variable, even in settings fed by rivers with similar discharges. This may be due to resetting of channel systems by delta-top channel avulsions or major offshore landslides, as well as the amount and rate of sediment supplied to the delta front by rivers.

Keywords: fjords, geomorphology, turbidity currents, processes, submarine channels, deltas 


\section{Introduction}

River deltas and associated turbidity current systems are important because they produce submarine fans, which are some of the largest and most rapid sediment accumulations on our planet (Nielsen et al., 2007). These thick deposits hold valuable oil and gas reserves (Weimar and Pettingill, 2007) and efficiently bury large volumes of organic carbon thereby playing a significant role in the global carbon cycle (Galy et al., 2007; Smith et al., 2015). Submarine deltas can produce remarkable submarine channel systems that extend offshore for tens or sometimes even thousands of kilometres (Clarke and Pickering, 1996; Babonneau et al., 2010;

Conway et al., 2012; Peakall and Sumner, 2015); rivalling even the largest terrestrial river networks. The factors that determine the origin and final extent of submarine channels are currently poorly understood compared to their terrestrial counterparts.

The morphology of delta and turbidity current systems matters for several reasons. First, turbidity currents are notoriously difficult to monitor directly (Inman et al., 1976; Talling, 2014), and direct measurements of deltaic processes are also challenging (Geyer et al., 2000). The processes that move sediment offshore within delta-fed turbidity current systems are also worthy of study because they pose a major hazard to expensive and strategic seafloor infrastructure, which includes oil and gas pipelines or fibre-optic telecommunication cables (Cooper et al., 2013; Carter et al., 2014). For example, well-developed submarine channels allow powerful turbidity currents to runout for much greater distances (Carter et al., 2014). System morphology may therefore provide important insights into how sediment transport processes work (Orton and Reading, 1993). Second, system morphology strongly influences the shape and location of valuable oil and gas reservoirs. This affects the 
shape and distribution of sand layers deposited by submarine channels, or in delta lobes (Weimer and Pettingill, 2007; Sylvester and Covault, 2016).

Most of the world's largest river deltas presently occur in shallow water on the flooded continental shelf. These river deltas can be characterised by factors influencing their morphology, including the characteristics of the rivers that feed them, the characteristics of the bodies of water the river enters, sediment load of the river, degree of wave and tidal currents, submerged gradient and presence of features such as mouth bars (Wright, 1977; Orton and Reading, 1993). Deltas entering deep-water were much more common during sea-level low-stand when rivers reached the continental shelf edge (Burgess and Hovius, 1988).

The largest delta-fed turbidity current systems that form submarine fans in the deep ocean are extremely expensive and time consuming to study in any detail. Here we study smaller-scale systems in a set of fjords in British Columbia. These marine fjords have been mapped and monitored in exceptional detail (Prior et al., 1987; Bornhold et al., 1994; Ren et al., 1996; Hughes Clarke, 2016; Shaw et al., 2017) and display a wide range of morphologies (Conway et al., 2012), making them an excellent natural laboratory to understand links between sedimentary processes and the resulting seafloor morphology. A characteristic feature of these fjords is that river mouths enter into waters that rapidly reach depths of up to $600 \mathrm{~m}$ (Fig. 1). Rivers that feed these British Columbia fjords almost never have hyperpycnal (plunging) river discharges, as suspended sediment concentrations are rarely great enough to generate hyperpycnal flows with average sediment concentrations $<1$ $\mathrm{kg} / \mathrm{m}^{3}$ (Macdonald, 1983; Hickin, 1989; Bornhold et al., 1994; Mulder and Syvitski, 1995; Hill et al., 2008; Hughes Clarke et al., 2014; Clare et al., 2016; Hughes Clarke, 2016). Settings dominated by hyperpycnal river discharges may thus experience 
different processes (Kostic et al., 2002; Mulder et al., 2003) and have different morphologies to those considered here (Best et al., 2005; Piper and Normark, 2009).

This study is timely because it uses high-resolution multibeam echo-sounder data that has recently become available across a wide range of fjords in British Columbia (Conway et al., 2012; Hughes Clarke et al., 2014, Hughes Clarke, 2016), and indeed elsewhere (e.g. Hill, 2012; Corella et al., 2013; Turmel et al., 2015; Clare et al., 2017). In some cases, repeat multibeam surveys provide novel and informative time-lapse images that document how systems evolve (Conway et al., 2012; Hughes Clarke, 2016). Previous work in these British Columbian fjords includes some of the most detailed measurements yet made of active turbidity currents (Prior et al., 1987; Zeng et al., 1991; Bornhold et al., 1994; Ren et al., 1996; Hughes Clarke et al., 2014; Hughes Clarke, 2016; Hage et al., 2018), which help to understand links between process and morphology. Such direct monitoring data also constrain the timing and hence triggers of turbidity currents (Hughes Clarke et al., 2014, Hughes Clarke, 2016), including their relationship to fluctuations in river discharge or tides (Ayranci et al., 2012; Clare et al., 2016; Hizzett et al., 2018). Previous studies of the fjords have been influential, for example producing detailed facies models (Syvitski and Farrow, 1983; Prior and Bornhold, 1989). These previous studies used information from the subaerially-exposed areas, together with offshore data from sub-bottom profilers, sidescan sonars and sediment cores. We are thus able to combine these previous facies models and high-resolution surveys to determine how system morphology is related to flow processes. These insights are captured here in a series of general models for turbidity current channel and delta systems in fjords and other deep-water settings.

\section{Aims}


We seek to understand what controls the morphology of deep-water deltas and associated turbidity currents systems, and thus how their morphology records key sedimentary processes. The aims are to (1) identify distinct types of delta and turbidity current systems in a series of deep-water fjords in British Columbia, and constrain the processes that control these highly variable morphologies; (2) to understand why well developed (up to $50 \mathrm{~km}$ long) submarine channel systems occur in some fjords, but not in others (Fig. 1; Conway et al., 2012); and (3) to present a general model that subdivides different morphologies of delta and turbidity current systems in locations such as these fjords, where river mouths discharge directly into relatively deep water.

\section{Study area}

This study focusses on five fjords in British Columbia, Canada, which are Howe Sound, Bute Inlet, Toba Inlet, Knight Inlet and Kitimat Arm (Fig. 1; Table 1). These glacially-carved fjords have a number of common characteristics (Table 1; Fig. 1). They are relatively deep and steep-sided; such that deltas prograde into water that rapidly reach depths of up to $650 \mathrm{~m}$ (Fig. 1). They are fed by one or more major rivers at the fjord heads, which drain from large watersheds within the mountainous hinterlands (Table 1). Small and steep river systems occur along the fjord flanks. The river catchments are influenced by seasonal spring and summer melt of glaciers. Peak river discharges during summer are up to ten times the baseline during winter, with short-lived flood discharges reaching over $1,000 \mathrm{~m}^{3} / \mathrm{s}$ and sometimes 3,000 $\mathrm{m}^{3} / \mathrm{s}$ in the summer and early autumn (Bornhold et al., 1994; Canadian Hydrographic Office data available from http://wateroffice.ec.gc.ca). The mean annual and maximum discharges for individual large fjord-head rivers are summarised in Table 
1. Typically, these fjord-head river beds and delta tops are dominated by fine-tocoarse sand or fine gravel (Syvitski and Farrow, 1983; Hickin, 1989; Hughes Clarke, 2016). The steeper and smaller catchments along the fjord sides tend to be even coarser grained (Prior and Bornhold, 1989). All of the fjords are affected by relatively strong tides, with ranges of 4-5 m during spring tides and generally experience small wave heights due to limited fetch for most wind directions (e.g. Hughes Clarke, 2016).

\section{Methods}

This study is based on new analyses of system morphology captured by multibeam bathymetry mapping, together with environmental data including river drainage area discharge, sediment concentration, glacial area and precipitation. This is combined with previously published insights into sedimentary processes from studies that monitored active flows (e.g. Hughes Clarke, 2016) or cored and mapped deposits using other geophysical methods (e.g. Prior and Bornhold, 1989; Stacey et al., 2018; Hage et al., 2018).

\section{Bathymetric data constraining seafloor morphology}

Multibeam bathymetric data were collected in Kitimat Arm, Knight Inlet, Bute Inlet, Toba Inlet and Howe Sound (Figs 2-6). These surveys were obtained by two vessels; the RV Vector operated by the Canadian Coastguard Service and the RV Heron operated by the University of New Brunswick. The Vector used a $100 \mathrm{kHz}$ Kongsberg-Simrad EM1002 system in 2005-2008, and a 70-100 kHz KongsbergSimrad EM710 system from 2010 onwards. The RV Heron used an EM710 multibeam operating at $70-100 \mathrm{kHz}$. Multibeam surveys were processed by the 
Canadian Hydrographic Service (CHS) and at the Universities of New Hampshire and New Brunswick. Data were processed using the Kongsberg SIS system and CARIS-HIPS (CUBE extension). The horizontal data resolution is $1-2 \mathrm{~m}$ due to navigational limitations, and the vertical resolution of the bathymetric measurements was typically $<0.5 \%$ of the water depth (Conway et al., 2012; Hughes Clarke et al., 2014).

ArcGIS software was used to produce hillshaded bathymetry, slope, roughness and bathymetric difference maps where repeat multibeam data were available. Difference plots of seafloor elevation were calculated using the Raster Calculator tool in ArcGIS. The difference plots are affected by cumulative errors in positioning in regions of rapid vertical change (e.g. at channel walls, fjord flanks). A small horizontal error may then lead to significant vertical error (Conway et al., 2012). ArcGIS software was also used to produce delta and submarine channel profiles by extracting bathymetric and slope gradient profiles.

\section{Statistical analyses of river drainages and delta morphology}

The relationship between river basin and delta morphology was analysed statistically. Principal component analysis (PCA) was used to determine which variables were most important in distinguishing between different delta types. Input variables included: delta area $\left(\mathrm{km}^{2}\right)$, delta gradient and area of associated river basins $\left(\mathrm{km}^{2}\right)$. Minitab v15 was used for PCA analysis. The data were normalised into dimensionless units and a correlation matrix calculated to determine correlations between the variables. Principal components were then calculated and those explaining $<10 \%$ of the variance in the data were excluded. Component scores were calculated to identify which parameters explained the most variance within the data. 
K-means clustering in Matlab was used to determine whether groups of submarine deltas identified through visual examination were indeed statistically significant. The statistical significance of the groups was calculated using the T-test and standard deviations were calculated to test whether the variance within the groups was less than the variance between the groups.

River characteristics: drainage basin area, discharge and sediment concentration

Daily river discharges were downloaded from Environmental Canada monitoring stations (https://wateroffice.ec.gc.ca) and all available data (up to 50 years-worth) were used to generate mean annual discharge values $\left(\mathrm{m}^{3} / \mathrm{s}\right)$. River stage and hence discharge measurements were available for the Kitimat River (station 08FF001), Homathko River that enters Bute Inlet (station 08GD004), Klinaklini River that enters into Knight Inlet (station 08GE002), Squamish River that enters Howe Sound (08GA022) and the Tahumming River (08GC003) (Table 1) that feeds into Toba Inlet. No discharge measurements are available for the Upper Toba river delta; the main river entering into Toba Inlet. To assess how often, and by how much, each river system was affected by elevated river discharge, the percentage of time that each river system exceeded mean annual river discharge was calculated along with the mean discharge value this was exceeded by for each river system.

Measured suspended sediment concentrations were obtained from Environmental Canada monitoring stations, where available. No data was available for Knight Inlet and Toba Inlet; therefore, these measurements were taken from the literature (Table 1). Mean sediment concentration values are provided that are averaged over the water column depth (Table 1). It must be noted that 
measurements in the fjords are sparse in places and measured using a range of equipment (e.g. D49 sampler in Kitimat; P61 sampler in Bute), therefore values of suspended sediment concentration should be used with caution.

A 30 m resolution terrestrial DEM of British Columbia (Canadian Hydrographic Survey) was used to assess drainage basin character. A shapefile of glacial coverage created by the Canadian Hydrographic Survey was used to infer glacial area. The glacial component of the drainage area (Table 1) was calculated by extracting the percentage glacial cover for each river drainage basin. Precipitation data were downloaded from Environmental Canada monitoring stations (Table 1). River drainage areas were obtained from Environmental Canada monitoring stations (http://wateroffice.ec.gc.ca). For Toba, only data from the Tahumming River were available which has a very small drainage area. A larger river (Upper Toba River) is present to the west with potentially greater drainage basin size and river discharge, hence two river drainage areas are provided for Toba Inlet (Table 1).

\section{Results}

The fjords can be subdivided into three main parts based on their morphology and longitudinal profile (Figs 2-6). Delta-fronts offshore from river mouths are relatively steep $\left(\sim 4^{\circ}\right)$ and tend to have decreasing gradients that produce a concave-upward long profile. A distinct break in slope occurs at the base of the delta front, and separates the delta-front from a lower, linear gradient $\left(\sim 1^{\circ}\right)$ area on which submarine channels are well developed (e.g. Bute Inlet, Knight Inlet, or Toba Inlet; Figs 3-5) or absent (Howe Sound and Kitimat Inlet (Figs 2 and 6)). Finally, a second slope break defines distal basin floors with particularly low $\left(<0.05^{\circ}\right)$ gradients. Frontal moraines 
with up to several hundred meters of relief form the termination of these mainly upper fjord systems (Fig 2A).

\section{Bimodal size and morphological character of deltas}

We first analyse the overall extent and morphology of these fjord-deltas. The total (subaerial and submarine) area and average seafloor gradient define two main types of fjord-deltas. First, high-gradient deltas are associated with small and steep drainage basins, which we term type 1 deltas. Second, low-gradient deltas are associated with distinctly larger drainage basins and are termed type 2. Type 1

deltas (123 examples; Fig. 7A) are much more common than type 2 deltas (14 examples; Fig. 7A), although they are much smaller. Type 1 and type 2 deltas plot as distinct clusters on an area versus gradient graph (Fig. 7A). The standard deviations of the standardized mean delta gradients (0.51 and 0.45$)$ and areas (0.36 and 1.78) for the two clusters are less than the difference between the means. This shows that the differences between the clusters are greater than the variance within the dataset, suggesting that the clusters are significant. The results of the T-test show that the results fall within the $95 \%$ significance level thereby suggesting that a significant difference exists between type 1 and type 2 deltas.

\section{Type 1 deltas: Smaller and steeper deltas fed by small mountainous}

rivers

Type 1 deltas can be further subdivided into two types based on their morphology. Type 1a deltas have a near uniform gradient (and thus linear profile) of $\sim 25^{\circ}$, and a mean offshore area of $0.24 \mathrm{~km}^{2}$. The surface of these type 1a deltas is predominantly smooth, such that lobes, channels, chutes and gullies are poorly 
developed or absent. In contrast, type $1 \mathrm{~b}$ deltas have a concave-upward profile (Fig. $8 \mathrm{~A}-\mathrm{F})$. Near to the source, type $1 \mathrm{~b}$ deltas have a mean gradient of $25^{\circ}$, but the average gradient on their lower reaches drops to $11^{\circ}$. The higher gradient upper delta-front is relatively smooth; but on the lower gradient lower reaches these deltas have well developed gullies, chutes, small-scale mass-wasting and sediment lobes (Fig. 8A-F). Type 1b deltas are typically somewhat bigger than type 1a deltas with a mean area of $0.67 \mathrm{~km}^{2}$ compared to $0.24 \mathrm{~km}^{2}$.

\section{Type 2 deltas: Larger and lower gradient fjord-head deltas fed by larger}

rivers

Distinctly larger and lower gradient (type 2) deltas are formed by rivers with much larger drainage basins. These rivers have continuous discharges that contrast with the smaller rivers with episodic discharges that produce type 1 deltas. Type 2 deltas occur at fjord heads and include the Kitimat River Delta in Kitimat Arm (Fig. 6), Klinaklini and Franklin River Deltas in Knight Inlet (Fig. 5), Homathko and Southgate River Deltas in Bute Inlet (Fig. 3), Toba River Delta in Toba Inlet (Fig. 4), and Squamish River Delta in Howe Sound (Fig. 2). Type 2 deltas are characterised by well-developed gullies that in some cases coalesce to form one or more channels that are incised into the delta front (Figs 2B, 5B). The gullies and channels contain ubiquitous bedforms that migrate upslope. Monitoring studies indicate that these delta-front gullies and channels are highly active, primarily during the summer freshet when river discharges are elevated (Hage et al., 2018); sometimes with over 100 individual flow events during a single year (Hughes Clarke et al., 2014, Hughes Clarke, 2016).

\section{Submarine channel development}


The development of submarine channels in the five studied fjords is highly variable

(Table 2; Figs 2-6), with channel lengths varying from a few kilometres on deltafronts to over $40 \mathrm{~km}$. In some fjords, channels are absent completely. The morphology of these channel systems are described below and in Table 2, starting with the best developed examples.

\section{Well-developed submarine channel systems extending from deltas (Knight, Bute and Toba Inlets)}

Channel systems in Bute, Knight and Toba Inlets are particularly well developed. In Bute and Knight Inlet, channels extend for over $40 \mathrm{~km}$ from the shoreline to water depths of $480-580 \mathrm{~m}$. In both locations, the channel system is fed by two large rivers with type 2 deltas. The channels have well developed terraces and their thalweg is typically $200 \mathrm{~m}$ to $300 \mathrm{~m}$ wide (Table 2; Figs 5A and 3A). The channel systems are eroded into the surrounding fjord floor, and depositional levees are weakly developed or absent. A striking feature of both channel systems is a series of steps along the channel profile (termed knickpoints), which have $10-40 \mathrm{~m}$ of relief (Figs 3C, $3 D, 5 C$ and 5D). The channel gradient is relatively uniform between these knickpoints. Time-lapse repeat bathymetric surveys of Conway et al. (2012) indicate that some of the knickpoints in Bute Inlet migrate up-slope (Figs 3C and 3D).

Both Bute and Knight Inlets have several secondary channels that either extend from the main channel and terminate on the fjord floor, or are disconnected from the main channel thalweg (termed here as headless channels). In many cases, the channels are associated with knickpoints (Fig. 5D). The headless channels are mainly concentrated on the lower section of the fjords where there is a distinct decrease in slope gradient to $<1^{\circ}$. 
Toba Inlet contains a well-developed channel that extends to water depths in excess of $400 \mathrm{~m}$. However, the main channel is not connected to the river-mouth, with the channel starting several kilometres beyond the delta-front at a major knickpoint (Fig. 4B). The main channel in Toba Inlet is therefore not directly connected to the highly active delta-front gullies and channels (Fig. 4), unlike the channels seen in Bute and Knight Inlets. A number of large (10-40 m high) knickpoints occur along the main channel axis in Toba Inlet, which also contains several headless channels (Fig. 4C). Difference calculations from repeat bathymetric surveys over consecutive years show migration of the knickpoints up-slope (Fig. 4C).

\section{Poorly developed submarine channel systems (Squamish and Kitimat}

\section{Delta)}

Squamish Delta has much more poorly developed submarine channels. Three channels are restricted to the delta-front, extending for only $2 \mathrm{~km}$ before terminating in lobes covered by active bedforms (Hughes Clarke et al., 2014; Hughes Clarke, 2016). Two partly infilled channels that are slightly longer $(\sim 3 \mathrm{~km})$ were previously abandoned, due to a man-made diversion of the main river course in 1971. The midlower part of the fjord is covered by numerous up-slope migrating bedforms. No channelization occurs here even though its gradient $\left(\sim 2^{\circ}\right)$ is comparable to that of channels in Bute and Knight Inlet. Finally, there is a distinct slope break to smooth distal basin floor (Fig. 2). Some shallow depressions that may represent incipient channel features occur in water depths of $\sim 180 \mathrm{~m}$. Channels are even more poorly developed offshore from the Kitimat River, as they extend for less than $1 \mathrm{~km}$ from the shoreline (Fig. 6). This location has been affected by a number of particularly large 
landslides in the 1970s, and potentially earlier. These large and overlapping landslide deposits have obscured any previously developed channels (Fig. 6).

\section{Flat deep-water basins}

Distinct slope breaks occur in the distal parts of Howe Sound, Bute Inlet, Knight Inlet and Toba Inlet (Figs 2-5) where particularly low gradients occur $\left(<0.05^{\circ}\right)$. We term this area the flat basin floor. Kitimat Arm lacks such a low gradient area in its distal parts and also lacks a ponded basin, as seen in other fjord systems (Fig. 6).

\section{Large-scale failure of fjord walls}

These five fjords display evidence of large-scale failure of fjord walls between deltas (e.g. Squamish Delta; Fig. 2C) or delta-fronts (e.g. Kitimat Delta; Fig. 6). These large-scale failures produce characteristically blocky landslide deposits that infill the fjord floors or channels.

\section{Discussion}

The main factors that determine delta-front morphology are discussed initially, followed by controls on the development of submarine channel systems. Insights from these five fjords in British Columbia are combined with wider global observations and compared to previous theoretical or numerical models. We then

outline a series of general models for deltas and linked turbidity current systems in locations where river discharges enter deep water rather than forming plunging hyperpycnal flows (Fig. 9).

\section{How is delta-front morphology linked to sedimentary process?}


Delta area is found to be strongly bimodal with steep and small fan deltas (type 1) and shallow and large fjord-head deltas (type 2).

Type 1a deltas: 123 high-gradient type 1 deltas associated with small and steep drainage basins occur within the five Canadian fjords. Eighty-six of these type 1 deltas show a linear geometry with mean slope gradients of $\sim 25^{\circ}$ and relatively homogenous surfaces (type 1a). The low drainage basin sizes $\left(<15 \mathrm{~km}^{2}\right)$ suggest low levels of bedload and suspended sediment transport and low stream discharge (Jopling, 1964; Allen, 1970). These systems are formed by avalanching of coarsegrained bedload delivered by steep mountainous rivers to produce small Gilbert-type fan-deltas, whose steep gradient $\left(11^{\circ}-25^{\circ}\right)$ approaches the sediment's angle of repose $\left(25^{\circ}\right.$ to $45^{\circ}$; Carrigy, 1970 ; Pohlman et al., 2006). The sediment transport carrying capacity is suddenly reduced causing sediment to be rapidly deposited, resulting in steep gradient foresets near the angle of repose (Gilbert, 1880). Finer sediment bypasses the slope-settling further down-fjord.

Type $1 \mathrm{~b}$ deltas: 37 deltas have a non-linear geometry (type $1 \mathrm{~b}$ deltas) where a distinct break in slope gradient occurs at $\sim 11-16^{\circ}$ (Fig. 8A-F). Above the break in slope, mean slope gradient is $25^{\circ}$ and the surface is relatively homogenous and similar in morphology to type 1a. Below this break in slope, mean gradients are $\sim 7^{\circ}$. Here, debris lobes, gullies, chutes and in some cases small channels and bedforms occur indicating that a threshold may exist for gully and chute formation on submarine deltas at $\sim 11-16^{\circ}$ as opposed to bypass or the delta remaining stable. These deltas are at the dynamic angle of repose, where gradients above the angle of repose $\left(\sim 25^{\circ}\right)$ occur, causing avalanching and destabilisation of the delta surface.

Type 2 deltas: There are 14 larger fjord-head (type 2) deltas that are associated with significantly larger drainage basin areas $\left(>990 \mathrm{~km}^{2}\right)$. These deltas 
have much lower gradients $\left(1.5^{\circ}-10^{\circ}\right)$ that decrease offshore in a near exponential fashion.

There has been a considerable body of work on the profile of deltas offshore from rivers, and continental shelves away from riverine input (Wright and Coleman, 1973; Syvitski et al., 1988; Wright, 1995; Pirmez et al., 1998; Friedrich and Wright, 2004). Here we consider deltas that are built into relatively deep water, and which are not dominated by wave action and resuspension of sediment (cf. Wright, 1995; Friedrichs and Wright, 2004). As in many other delta systems (Pirmez et al., 1998), there is a sigmoidal shape to the overall delta profile with a low gradient top-set, and a steep upper delta slope (fore-set) whose slope decreases offshore (toe-set). In general, this sigmoidal shape is linked to maximum sedimentation rates that occur on the upper fore-set (Pirmez et al., 1998). In the fjords analysed, there is a particularly sharp inflexion point between the topset and foreset, which coincides with avalanching of bedload at the river mouth (Fig. 9); whilst in other types of setting the inflexion point can be in deeper water (Pirmez et al., 1998).

In the studied fjords, sediment transport and delta-morphology is dominated by delta-lip failures, and turbidity currents triggered by those failures, or settling from surface (homopycnal) plumes (Clare et al., 2016; Hughes Clarke, 2016; Hizzett et al., 2018). Hyperpycnal flows that are produced directly by river input with high suspended sediment concentrations are rare in these fjords because typical suspended sediment concentrations (e.g. 0.008-0.7 kg/m³; Table 1) are rarely great enough to overcome the excess density required for plunging flows (Mulder and Syvitski, 1995). Several processes combine to cause a decrease in sedimentation rate with distance offshore, and this decrease in sedimentation rate leads to the concave-up delta front (fore-set and toe-set) profile. First, the delta-lip itself can 
prograde by up to $10 \mathrm{~m}$ in a single flood, as bedload is driven over the delta-lip (Hughes Clarke, 2016), leading to landslides. Second, sedimentation rates from the surface plume decrease offshore, and this may dominate sedimentation outside delta-front channels (Hughes Clarke, 2016; Stacey et al., 2018). Finally, turbidity currents are most commonly triggered from sediment settling from surface (homopycnal) plumes (Hizzett et al., 2018). These flows are associated with channel cutting, bedforms and sediment bypass into deeper water (Clare et al., 2016; Hughes Clarke, 2016; Hage et al., 2018; Hizzett et al., 2018; Stacey et al., 2018). Field examples where similar delta morphologies are observed include the Rhine Delta (Hinderer, 2001) and Colorado River Delta in Lake Mead (Smith et al., 1960).

\section{What controls the development of submarine channels?}

Large and deeply-entrenched channels occur in some of the studied fjords (Knight, Toba and Bute Inlets; and Howe Sound), although there is a striking difference in the length of the channels, even in settings fed by rivers with similar discharges (e.g. Bute Inlet and Howe Sound). Avulsion of the river mouth may cause submarine channel systems to be abandoned, and to regrow, as potentially seen in Squamish Delta (Hughes Clarke, 2016) and Toba Inlet, where the main channel begins several $\mathrm{km}$ after the delta front. In all fjord systems, the channels are cut below the surrounding seafloor and have rather poorly developed levees. Terraces occur in all systems (excluding Kitimat Arm) indicating well-developed and deep thalweg incision. This indicates that the systems are primarily erosional, rather than forming by the build-up of levees at the sides of the channel. The main channels within the fjords have distinctly linear channel long-profiles (Fig. 7C) with gradient decreasing with distance from the main delta-front at the fjord head, where high concavity 
occurs. Here, terraces, deep channel entrenchment, crescentic shaped bedforms and scarps are common. In the following sections, we discuss how the observed differences in submarine channel characteristics relate to the processes controlling their morphology.

\section{Importance of knickpoints for channel formation and maintenance}

Below the delta-front, the channel long-axis are distinctly linear with extremely low variances in gradient over tens of $\mathrm{km}$. Local variations along the thalweg are due to knickpoints causing localised increases in slope gradient in all channel systems and also within headless channels both connected to and disconnected from the main channel. These knickpoints are between 20 and $40 \mathrm{~m}$ high and cut into previous deposits. Although locally the knickpoints result in a section of anomalously steep gradient, mean slope gradient decreases between consecutive knickpoints, thus maintaining the channel linearity. High-resolution repeat surveys over the knickpoints (e.g. Figs 3C and 3D) show that these move up-slope toward the delta front, in some cases $\sim 1300$ m over five years. The knickpoints along the channel periodically fail, increasing the depth of the channel locally, thus increasing channel entrenchment. As sediment or debris lobes located down-slope of the knickpoints are uncommon, this suggests that either the knickpoint failure generated a debris flow which transformed into a turbidity current, or the failure deposit was flushed down-channel by a turbidity current event generated further up-slope of the knickpoint. As knickpoints are present down the entire channel axis, this may explain how the linear channel morphology is maintained.

Knickpoints are common in other locations worldwide, although their morphology and formation mechanisms may differ. They are observed in erosional 
canyons (e.g. Astoria Canyon, Oregon; San Antonia Canyon, Chile; Monterey Canyon, California; Scripts Canyon, California; Mitchell, 2006; Mitchell, 2014); on open continental slopes (New Jersey continental slope; Mitchell, 2006); as deepwater 'waterfalls' (e.g. Monterey Fan; Masson et al., 1995); within headless channels (e.g. Lake Geneva; Girardclos et al., 2012); in lakes (e.g. Lake Geneva; Lake Wabush; Girardclos et al., 2012; Turmel et al., 2015); and in channel meander bed cut-offs (e.g. offshore Angola; Sylvester and Covault, 2016).

\section{Headless and proto-channels - the early stages of channel development?}

In Bute, Knight and Toba Inlets, headless channels occur either branching off the main channel thalweg or as isolated secondary channels. The occurrence of headless channels may indicate early stages of channel development. These headless channels have high-gradient heads and similar gradient axis to the main channel thalwegs. For some headless channels, small chute-like depressions are observed at the heads of the channels (Fig. 5D) and difference calculations from repeat bathymetric surveys over consecutive years (Fig. 3C, D) show erosion (in the range of metres) at the channel heads.

The headless channels are mainly concentrated in the lower section of the fjords where a distinct decrease in slope gradient occurs to $\sim 1^{\circ}$. Here, bedforms are not commonly observed within the headless channels but sediment lobes are observed at the main channel terminus. Headless channels are also observed in other locations, for example Lake Geneva, where they are also concentrated toward the terminus of the main channel axis (Girardclos et al., 2012). The inception of these channels, concentrated in the lower section of the fjords, likely form from the 
interaction of overriding turbidity currents with seafloor perturbations or pits (Covault et al., 2014; Fildani et al., 2013).

\section{Relationship between submarine channels and river discharge}

Within the fjords analysed, river discharge characteristics (Table 1) exert a major influence on submarine channel development (Table 2). Knight and Bute Inlets are fed by the largest river systems, with greatest drainage basin area and highest mean annual discharges. These fjords have the longest channel systems, with wellestablished and $>40 \mathrm{~km}$ long channels. Clare et al. (2016) show that elevated river discharge was the primary control for the frequency of turbidity current events on Squamish Delta. For every $1 \mathrm{~m}^{3} / \mathrm{s}$ increase in river discharge above a threshold value (mean annual river discharge), the rate that turbidity currents occur increases by $0.6 \%$ (Clare et al., 2016). As suspended sediment concentrations from the fjord head rivers (Table 1 ) are not high enough to produce hyperpycnal flows (e.g. Mulder and Syvitski, 1995), the sediment flows are likely to be generated by failure of the delta lip and/or increased sediment concentration from hypopycnal river plumes. Here, turbidity currents are generated through sediment settling where freshwater can become entrained, leading to excess density and the generation of turbidity currents (Maxworthy, 1999; Yu et al., 2000; Parsons et al., 2001; Snow and Sutherland, 2014; Jazi and Wells, 2018). Hizzett et al. (2018) show that these flows generated by settling plume events also tend to coincide with peaks in river discharge.

Over the last 50 years (or data available), Bute Inlet exceeded its threshold discharge value (mean annual discharge) $60 \%$ of the time, whereas Knight, Kitimat 
and Toba Inlets and Howe Sound exceeded their threshold values $36-40 \%$ of the time. The mean discharge that the threshold was exceeded by varied widely with Knight and Bute Inlets displaying the highest values (Table 1). For Bute Inlet, the threshold was exceeded $60 \%$ of the time by a mean discharge of $302 \mathrm{~m}^{3} / \mathrm{s}$. For Knight Inlet, the threshold was exceeded $36 \%$ of the time by a mean discharge of $326 \mathrm{~m}^{3} / \mathrm{s}$. Howe Sound and Kitimat Arm had lower mean excess discharges of $<200$ $\mathrm{m}^{3} / \mathrm{s}$ and Toba Inlet (Tahumming River) was significantly lower still $\left(22 \mathrm{~m}^{3} / \mathrm{s}\right.$ ).

Bute and Knight Inlets experience either prolonged periods of significantly elevated river discharges, and/or exceptionally high river discharges. As river discharge increases, the frequency of turbidity current events also increases leading to significantly greater turbidity current activity in Knight and Bute Inlets. These flows, most likely generated by settling plume events, also tend to have the longest runouts and therefore are most important in terms of channel extension (Hizzett et al., 2018). The increased frequency of erosive, channel forming flows in Bute and Knight Inlets leads to the enhanced development of submarine channels.

Increased river discharge over short time periods can also lead to increased sediment build-up on the delta-lip, which ultimately fail and generate turbidity currents which run-out down-slope (Hughes Clarke et al., 2014; Clare et al., 2016). The highest values of suspended sediment concentration are measured in Knight and Bute Inlets $\left(0.7 \mathrm{~kg} / \mathrm{m}^{3}\right.$ and $0.5 \mathrm{~kg} / \mathrm{m}^{3}$ respectively; Table 1$)$. This elevated river discharge results in increased sediment build-up on the delta top and lip which may trigger delta-lip collapse. However, Hizzett et al. (2018) note that the size of the collapse does not necessarily influence the size of the sediment flow generated, with larger delta-lip collapse (up to $150,000 \mathrm{~m}^{3}$ ) often having relatively short runout 
distances. Therefore it is likely that the increased frequency and erosive nature of sediment flows generated by settling of sediment from surface plumes tend to have the greatest influence on channel system morphology within these fjords.

No hydrographic stations are present in the lower reaches of the Toba River; thus, the only available river discharge measurements are from the much smaller Tahumming River (Fig. 4). However, as river discharge is influenced by factors such as drainage basin area, watershed length and glacial component, which were calculated from regional DEMs (Table 1), river discharge from the Upper Toba River are assumed to be similar to Kitimat and Squamish Rivers. Toba Inlet is notable because it has a well-developed submarine channel that is separated from the main delta system by several $\mathrm{km}$ (Fig. 4B). We propose that the main channel once connected through to the river mouth, but that delta front avulsion (or other processes) then caused the main channel system to be abandoned, and the proximal part of that channel was then infilled and buried. Conway et al. (2012) show that the delta system is active with a new channel developing between 2008-2010 on the upper delta slope (Fig. 4C), similar in morphology to the short channels observed in Squamish Delta. The main channel is now disconnected from the delta system, and its previous character may reflect past conditions with enhanced annual river discharge. Reduced sediment discharge from the river may be due to factors such as the construction of run-of-the-river hydroelectricity generation plants in Toba Inlet in 2010, and which divert up to $98 \%$ of the stream capacity (Gower et al., 2012). However, as there is no data from the larger rivers monitoring stations, this remains uncertain. Kitimat Delta also has a comparatively low drainage basin area and river discharge and very poorly developed channels that incise submarine landslide deposits (Fig. 6), indicating a system reset by major slides (Fig. 9d). 


\section{General models: delta and submarine channel development}

Why submarine channels develop in some fjords and not others is central for understanding the factors influencing turbidity current systems. We provide a series of general models that summarise dominant processes and resulting morphologies of turbidity current systems linked to deltas entering deep water settings that are not influenced by hyperpycnal flows (Fig. 9).

\section{High gradient deltas dominated by avalanching of coarse bedload}

Gilbert (Type 1) deltas are associated with relatively small and steep river drainage basins, which supply coarse grained sediment (Fig. 9A). The associated delta is dominated by avalanching of this coarse bedload. Surface plumes of finer sediment are more poorly developed due to smaller drainage basin areas and associated watersheds. The delta front has steep gradients of $20-30^{\circ}$ that approaches the angle of repose, favouring remobilisation of dense granular flows. In some cases (type 1b), the delta is concave-upward and its lower-gradient and more distal reaches are dissected by gullies. These erosional features may be formed by longer run-out turbidity currents generated by the initial bedload avalanches or small-scale slope failure.

Hybrid surface plume and delta-lip failure deltas with no or poorly developed channels

The second type of delta-system either completely lacks, or has poorly developed, submarine channels, such as Squamish Delta. This system has a concave-upward profile influenced by a combination of sediment settling from surface plumes and delta-lip failure (Fig. 9B). Channels occur where turbidity currents, generated by 
sediment settling from surface plumes or delta-lip failure, are sufficiently powerful to cut weakly developed channels into the delta-front. These systems tend to have smaller drainage basins, river discharges and sediment concentrations (Fig. 9B), which reduces the frequency of turbidity currents, and thus likelihood of erosive turbidity currents reaching the channel terminus (Clare et al., 2016; Hizzett et al., 2018). Turbidity currents within the proximal channels tend to be supercritical, and produce cyclic steps and coarse-grained bedforms that migrate upslope (Hughes Clarke, 2016; Stacey et al., 2018).

\section{Hybrid surface plume and delta-lip failure deltas with extensive channels}

The third type of delta-system has well developed and extensive submarine channels (Fig. 9C), such as Knight, Bute and Toba Inlets (Table 2). Channels eroded by turbidity currents become better developed as the percentage of time and magnitude that a river system exceeds the threshold mean annual discharge level by increases. These systems tend to have larger drainage basins, river discharges and sediment concentrations (Fig. 9C). This increases the frequency of erosive turbidity currents formed by settling from surface plumes and/or delta-lip failures as more sediment is deposited rapidly on the delta-lip which episodically fails, generating turbidity currents (Clare et al., 2016). Deeply entrenched submarine channel systems are formed, partly by series of up-slope migrating knickpoints. Headless channels may also form in distal regions. Avulsion at the delta front may cause an extensive channel system to become disconnected from the river mouth. The proximal part of the relict channel is then infilled and buried, and much shorter channels develop initially beyond the new river mouth (Fig. 4B). This disconnection of submarine channel and river mouth causes a change from a type 3 (Fig. 9C) to type 2 (Fig. 9B) system, as inferred for Toba Inlet (Fig. 4). 


\section{Delta morphologies that are reset by widespread slope failure}

Widespread slope failures can wipe out any preceding channel systems on deltas, and thus reset the submarine channel systems (Fig. 9D). Slope failures can be triggered by earthquakes, or by low tides and other factors as seen at Kitimat Arm where there is evidence for at least 15 Holocene slides (Shaw et al., 2017).

\section{Conclusions}

This contribution seeks to understand the main factors that control the morphology of turbidity current systems linked to deltas, and why some locations have well developed submarine channels whilst others do not. Delta morphology is found to be strongly bimodal within a series of adjacent fjords in British Columbia, Canada. This is primarily due to bimodality in river drainage and basin character. The longest ( $>40$ $\mathrm{km}$ ) and most established submarine channels were found in the fjords where threshold mean annual discharge values were exceeded over prolonged periods (e.g. Bute Inlet); or where the mean discharge this was exceed by was significantly high (e.g. Knight and Bute Inlets). River avulsion and widespread submarine landslides can both act to reset these submarine channel systems.

These insights are captured in a series of general models for delta and turbidity channel systems (Fig. 9). This includes: 1) High-gradient deltas dominated by avalanching of coarse bedload. Here, Gilbert deltas are common on the flanks of fjords where the steep-sloped delta morphology $\left(20-30^{\circ}\right)$ is largely controlled by small and steep river drainage basins. Gullies and chutes occur on some of the distal reaches. 2) Hybrid surface plume and delta-lip failure deltas with no or poorly developed channels. This system either lacks or has poorly developed channels. The concave-upward system geometry is formed by a combination of sediment 
settling from surface plumes or delta-lip failure. These systems are characterised by smaller drainage basin sizes and lower river discharges. 3) Hybrid surface plume and delta-lip failure deltas with extensive channels. This system is characterised by well-developed and extensive submarine channels. Increased river discharge and magnitude that river discharge exceeds annual threshold values by, favours formation of longer erosive turbidity current channels. 4) Delta morphologies reset by widespread slope failure. These systems are characterised by widespread slope failure that may wipe out any preceding channels and thus reset the submarine channel system.

\section{Acknowledgements}

We thank Jeff Peakall, one anonymous reviewer and the Associate Editor for their insightful reviews which substantially improved the manuscript. We acknowledge Natural Environment Research Council funding (grants NE/M007138/1, NE/M017540/1, NE/P009190/1, and NE/P005780/1).

\section{References}

Allen JRL. 1970. A quantitative model of grain size and sedimentary structure in lateral deposits. Geological Journal 7: 129-146.

Ayranci K, Lintern DG, Hill PR, Dashtgard SE. 2012. Tide-supported gravity flows on the upper delta front, Fraser River delta, Canada. Marine Geology 326: 166-170.

Babonneau N, Savoye B, Cremer M, Bez M. 2010. Sedimentary architecture in meanders of a submarine channel: detailed study of the present Congo turbidite channel (Zaiango Project). Journal of Sedimentary Research 80: 852-866. 
Best JL, Kostaschuk RA, Peakall J, Villard PV, Franklin M. 2005. Whole flow field dynamics and velocity pulsing within natural sediment-laden underflows. Geology 33: 765-768.

Bornhold BD, Ren P, Prior DB. 1994. High-frequency turbidity currents in British Colombia fjords. Geo-Marine Letters 14: 238-243.

Burgess PM, Hovius N. 1998. Rates of delta progradation during highstands: consequences for timing and deposition in deep-marine systems. Journal of the Geological Society 155: 217-222.

Carrigy MA. 1970. Experiments on the angles of repose of granular materials. Sedimentology 14: 147-158.

Carter L, Gavey R, Talling PJ, Liu JT. 2014. Insights into submarine geohazards from breaks in subsea telecommunication cables. Oceanography 27: 58-67.

Clare MA, Hughes Clarke JE, Talling PJ, Cartigny MJB, Pratomo DG. 2016. Preconditioning and triggering of offshore slope failures and turbidity currents revealed by most detailed monitoring yet at a fjord-head delta. Earth and Planetary Science Letters 450: 208-220.

Clare MA, Vardy ME, Cartigny MJB, Talling PJ, Himsworth MD, Dix JK, Harris J, Whitehouse R, Belal M. 2017. Direct monitoring of active geohazards: emerging geophysical tools for deep-water assessments. Near surface geophysics 15: 427444.

Clarke JD, Pickering KT. 1996. Architectural elements and growth patterns of submarine channels: Applications to hydrocarbon exploration. AAPG Bulletin 90: 194-220.

Conway KW, Barrie JV, Picard K, Bornhold BD. 2012. Submarine channel 
evolution: active channels in fjords, British Columbia, Canada. Geo-Marine Letters 32: $301-312$.

Cooper C, Wood J, Andrieux A. 2013. Turbidity current activity in the Congo Canyon. OTC 23992. Offshore Technology Conference, 6-9 May, 12, Houston, Texas. 12 pp. Corella JP, Arantegui A, Loizeau JL, DelSontro T, le Dantec N, Stark N, Anselmetti, FS, Girardclos S. 2013. Sediment dynamics in the subaquatic channel of the Rhode delta (Lake Geneva, France/Switzerland). Aquatic Sciences 76: S73-S8.

Covault JA, Kostic S, Paull C, Ryan HF, Fildani A. 2014. Submarine channel initiation, filling and maintenance from sea-floor geomorphology and morphodynamic modelling of cyclic steps. Sedimentology 61: 1031-1054.

Fildani A, Hubbard SM, Covault JA, Maier KL, Romans BW, Traer M, Rowland JC. 2013. Erosion at inception of deep-sea channels. Marine Petroleum Geology 41: 4861.

Friedrichs CT, Wright LD. 2004. Gravity-driven sediment transport on the continental shelf: implications for equilibrium profiles near river mouths. Coastal Engineering 51: 795-811.

Galy V, France-Lanord C, Beyssac O, Faure P, Kudrass H, Palhol F. 2007. Efficient organic carbon burial in the Bengal fan sustained by the Himalayan erosional system. Nature 450: 407-410.

Geyer WR, Hill P, Milligan T, Traykovski P. 2000. The structure of the Eel River plume during floods. Continental Shelf Research 20: 2067-2093.

Gilbert GK. 1880. Lake Bonneville. U.S. Geological Survey Monography 1: 435.

Girardclos S, Hilbe M, Corella JP, Loizeau J-L, Kremer K, Delsontro T, Argantegui A, Moscariello A, Arlaud F, Akhtman Y, Anselmetti FS, Lemmin U. 2012. Searching the 
Rhone delta channel in Lake Geneva since François-Alphonse Forel. Archives Science 65: 103-118.

Gower T, Rosenberger A, Peatt A, Hill A. 2012. Tamed Rivers: A guide to river diversion hydropower in British Columbia. Prepared for Watershed Watch Salmon Society. 64 pp.

Hage S, Cartigny MJ, Clare MA, Sumner EJ, Vendettuoli D, Hughes Clarke JE, Hubbard SM, Talling PJ, Lintern DG, Stacey CD, Englert RG, Vardy ME, Hunt JE, Yokokawa M, Parsons DR, Hizzett JL, Azpiroz-Zabala M, Vellinga A. 2018. How to recognize crescentic bedforms formed by supercritical turbidity currents in the geologic record: Insights from active submarine channels. Geology 46: 563-566.

Hickin EJ. 1989. Contemporary Squamish river sediment flux to Howe Sound, British Columbia. Canadian Journal of Earth Sciences 26: 1953-1963.

Hill P. 2012. Changes in submarine channel morphology and slope sedimentation patterns from repeat multibeam surveys in the Fraser River delta, western Canada. International Association of Sedimentologists Special Publication 44: 47-70.

Hill P, Conway K, Lintern DG, Meulé S, Picard K, Barrie JV. 2008. Sedimentary processes and sediment dispersal in the southern Strait of Georgia, BC, Canada. Marine Environmental Research 66: S39-S48.

Hinderer M. 2001. Late Quaternary denudation of the Alps, valley and lake fillings and modern river loads. Geodinamica Acta 14: 231-263.

Hizzett JL, Hughes Clarke JE, Sumner EJ, Cartigny MJB, Talling PJ, Clare MA. 2018. Which triggers produce the most erosive, frequent and longest runout turbidity currents on deltas? Geophysical Research Letters 45: 855-863. 
Hughes Clarke JE. 2016. First wide-angle view of channelized turbidity currents linking migrating cyclic steps to flow characteristics. Nature Communications 7: 118960. http://dx.doi.org/10.1038/ncomms11896.

Hughes Clarke JE, Vidiera Marques CR, Pratomo D. 2014. Imaging active masswasting and sediment flows on a fjord delta, Squamish, British Columbia. In: Submarine Mass Movements and Their Consequences 37. Springer International Publishing. 249-260.

Inman DL, Nordstrom CE, Flick RE. 1976. Currents in submarine canyons: An airsea-land interaction. Annual Review of Fluid Mechanics 8: 275-310.

Jazi DS, Wells M. 2018. Settling-driven convection limits the spatial scale of deposition beneath sediment-laden buoyant flows in lakes and the coastal ocean. Sedimentology Accepted Article: doi:10.17605/OSF.10/9XYMN.

Jopling AV. 1964. Laboratory study of sorting processes related to flow separation. Journal of Geophysical Research 69: 3403-3418.

Kostic S, Parker G, Marr JG. 2002. Role of turbidity currents in setting the foreset slope of clinoforms prograding into standing water. Journal of Sedimentary Research 72: 353-362.

Macdonald RW. 1983. Proceedings of a workshop on the Kitimat marine environment. Canadian Technical Report of Hydrography and Ocean Sciences 18: $1-218$.

Masson DG, Kenyon NH, Gardner JV, Field ME. 1995. Monterey Fan: channel and overbank morphology. In: Atlas of Deep Water Environments: Turbidity system architectural styles. London. 74-79.

Maxworthy T. 1999. The dynamics of sedimenting surface gravity flows. Journal of Fluid Mechanics 392: 27-44. 
Mitchell NC. 2006. Morphologies of knickpoints in submarine canyons. Bulletin of Geological Society of America 118: 589-605.

Mitchell, NC. 2014. Bedrock erosion by sedimentary flows in submarine canyons. Geosphere 10: doi.org/10.1130/GES01008.1.

Mulder T, Syvitski JPM. 1995. Turbidity currents generated at river mouths during exceptional discharges to the worlds oceans. Journal of Geology 103: 285-299.

Mulder T, Syvitski JPM, Migneon S, Faugeres JC, Savoy B. 2003. Marine hyperpycnal flows: initiation, behavior, and related deposits. A review. Marine and Petroleum Geology 20: 861-882.

Nielsen T, Shew RD, Steffens GS, Studlick JRJ. 2007. Atlas of deepwater outcrops. AAPG Studies in Geology 56. Shell Exploration and Production and American Association of Petroleum Geologists: 504 pp.

Orton GJ, Reading HG. 1993. Variability of deltaic processes in terms of sediment supply, with particular emphasis on grain size. Sedimentology 40: 475-512.

Parsons JD, Bush JWM, Syvitski JPM. 2001. Hyperpycnal plume formation from riverine overflows with small sediment concentrations. Sedimentology 48: 465-478.

Peakall J, Sumner EJ. 2015. Submarine channel flow processes and deposits: A process-product perspective. Geomorphology 244: 95-120.

Piper DJW, Normark WR. 2009. Processes that initiate turbidity currents and their influence on turbidites: a marine geology perspective. Journal of Sedimentary Research 79: 347-362.

Pirmez C, Pratson LF, Steckler MS. 1998. Clinoform development by advectiondiffusion of suspended sediment: modelling and comparison to natural systems. Journal of Geophysical Research 103: 24141-24157. 
Pohlman NA, Severson BL, Ottino JM, Lueptow R. 2006. Surface roughness effects in granular matter: influence on angle of repose and the absence of segregation. Physical Review 73: DOI:10.1103/PhysRevE.73.031304.

Prior DB, Bornhold BD. 1989. Submarine sedimentation on a developing Holocene fan delta. Sedimentology 36: 1053-1076.

Prior DB, Bornhold BD, Wiseman Jr WJ, Lowe DR. 1987. Turbidity current activity in a British Columbia fjord. Science 237: 1330-1333.

Reading HG, Collison, JD. 1996. Clastic Coasts. In: Sedimentary Environments: Process Facies and Stratigraphy. Blackwell Publishing Company, Maiden, MA. 154-231 pp. Ren P, Bornhold BD, Prior DB. 1996. Seafloor morphology and sedimentary processes, Knight Inlet, British Colombia. Sedimentary Geology 103: 201-228.

Shaw J, Stacey C, Wu Y, Lintern G. 2017. Anatomy of the Kitimat fjord system, British Columbia. Geomorphology 293: 108-129.

Smith RW, Bianchi TS, Allison M, Savage C, Galy V. 2015. High rates of organic carbon burial in fjord sediments globally. Nature Geoscience 8: 450-453.

Smith WO, Vetter CP, Cummings GB. 1960. Comprehensive survey of sedimentation in Lake Mead, 1948-1949. US Geological Survey Profession Paper 295: $253 \mathrm{pp}$.

Snow K, Sutherland BR. 2014. Particle-laden flow down a slope in uniform stratification. Journal of Fluid Mechanics 755: 251-273.

Stacey CD, Hill PR, Talling PJ, Enkin RJ, Hughes Clarke JE, Lintern DG. 2018. How turbidity current frequency and character varies down a fjord-delta system: combining direct monitoring, deposits and seismic data. Sedimentology 36: 217-244. Sylvester S, Covault JA. 2016. Development of cutoff-related knickpoints during early evolution of submarine channels. Geology 44(10): doi:10.1130/G38397.1. 
Syvitski JPM, Milliman JD. 2007. Geology, geography and humans battle for dominance over the delivery of sediment to the coastal ocean. Journal of Geology 115: 1-19.

Syvitski JPM, Smith JN, Calabrese EA, Boudreau BP.1988. Basin sedimentation and the growth of prograding deltas. Journal of Geophysical Research Atmospheres 93: 6895-6908.

Talling PJ. 2014. On the triggers, resulting flow types and frequency of subaqueous sediment density flows in different settings. Marine Geology 352: 155-182.

Turmel D, Parker G, Locat J. 2015. Evolution of an anthropic source-to-sink system: Wabush Lake. Earth Science Reviews 151: 227-243.

Weimer P, Pettingill HS. 2007. A global overview of fields and discoveries in deep water deposits. AAPG Studies in Geology 56, Shell Exploration and Production and American Association of Petroleum Geologists: 12-16.

Wright LD. 1977. Sediment transport and deposition at river mouths: a synthesis. Geological Society of America Bulletin 88: 857-868.

Wright LD. 1995. Morphodynamics of Inner Continental Shelves. CRP Press, Boca Raton, FL, USA. 241 pp.

Wright LD, Coleman JM. 1973. Variations in morphology of major river deltas as functions of ocean wave and river discharge regimes. American Association of Petroleum Geologists Bulletin 57: 370-398.

Yu WS, Lee HY, Hsu SM. 2000. Experiments on deposition behaviour of fine sediment in a reservoir. Journal of Hydraulic Engineering 126: 912-920.

Zeng JJ, Lowe DR, Prior DB, Wiseman WJ, Bornhold BD. 1991. Flow properties of turbidity currents in Bute Inlet, British Colombia. Sedimentology 38: 975-996. 


\section{Tables}

Table 1. Environmental parameters associated with five Canadian fjord deltas.

\begin{tabular}{|c|c|c|c|c|c|c|c|c|c|}
\hline Fjord & $\begin{array}{c}\text { Draina } \\
\text { ge } \\
\text { area } \\
\left(\mathrm{km}^{2}\right) \\
{[1]}\end{array}$ & $\begin{array}{c}\text { Glacial } \\
\text { compone } \\
\text { nt } \\
\text { of the } \\
\text { drainage } \\
\text { area \% [3] }\end{array}$ & $\begin{array}{c}\text { Mean } \\
\text { annual } \\
\text { discharg } \\
\mathrm{e}\left(\mathrm{m}^{3} / \mathrm{s}\right) \\
{[1]}\end{array}$ & $\begin{array}{c}\text { Maximum } \\
\text { annual } \\
\text { discharge } \\
\left(\mathrm{m}^{3} / \mathrm{s}\right)[1]\end{array}$ & $\begin{array}{l}\text { Mean annual } \\
\text { precipitation } \\
(\mathrm{mm})\end{array}$ & $\begin{array}{c}\text { Measured } \\
\text { suspended } \\
\text { sediment } \\
\text { concentrat } \\
\text { ion }\left(\mathrm{kg} / \mathrm{m}^{3}\right)\end{array}$ & $\begin{array}{c}\text { Annual } \\
\text { sediment } \\
\text { discharge }^{\star} \\
\text { (suspended } \\
\text { load) }\end{array}$ & $\begin{array}{c}\text { \% values } \\
\text { exceeding } \\
\text { threshold } \\
\text { mean } \\
\text { annual } \\
\text { discharge } \\
{[14]}\end{array}$ & $\begin{array}{c}\text { Mean } \\
\text { excess } \\
\text { threshold } \\
\text { discharge } \\
\left(\mathrm{m}^{3} / \mathrm{s}\right)[15]\end{array}$ \\
\hline $\begin{array}{c}\text { Kitimat } \\
\text { Arm } \\
\text { (Kitimat } \\
\text { River }\end{array}$ & 1,990 & 3.5 & 123 & 1065 & $1,767[4]$ & $\begin{array}{c}0.008- \\
0.047[7]\end{array}$ & $\begin{array}{c}18 \times 10^{6} \\
\text { tons yr [11] }\end{array}$ & 38 & 111 \\
\hline $\begin{array}{l}\text { Knight } \\
\text { Inlet } \\
\text { (Klinakli } \\
\text { ni River) }\end{array}$ & $5,7 \varepsilon$ & 12.9 & 266 & 1,272 & $2,316[5]$ & $0.7[8]$ & $\begin{array}{l}1.7 \times 10^{6} \\
\text { tons yr [12] }\end{array}$ & 36 & 326 \\
\hline $\begin{array}{c}\text { Bute } \\
\text { Inlet } \\
\text { (Homath } \\
\text { ko } \\
\text { River) }\end{array}$ & 5,680 & 20.6 & 255 & 1,492 & $2,316[5]$ & $\begin{array}{c}0.403- \\
0.689[9]\end{array}$ & $\begin{array}{l}1.7 \times 10^{6} \\
\text { tons yr [12] }\end{array}$ & 60 & 302 \\
\hline $\begin{array}{c}\text { Howe } \\
\text { Sound } \\
\text { (Squami } \\
\text { sh } \\
\text { River) }\end{array}$ & 2,35 & 27 & 221 & 1427 & $2,341[6]$ & $0.04[10]$ & $\begin{array}{l}1.81 \times 10^{6} \\
\text { tons yr [13] }\end{array}$ & 40 & 198 \\
\hline $\begin{array}{c}\text { Toba } \\
\text { Inlet } \\
\text { (Tahum } \\
\text { ming } \\
\text { River) }\end{array}$ & $\begin{array}{c}233 ; \\
(1,759) \\
{[2]}\end{array}$ & 8; (36) [2] & 25 & 235 & $2,316[5]$ & - & - & 38 & 22 \\
\hline
\end{tabular}

[1] Environment Canada (https://wateroffice.ec.gc.ca): Kitimat: 08FF001; Knight: 08GE002;

Bute: 08GD004; Howe Sound: 08GA022; Toba: 08GC003 (Tahumming River; not main river input).

[2] Numbers in brackets calculated from ArcGIS for Upper Toba river. There is no monitoring station for this river.

[3] Calculated \% glacial cover of total drainage area. 
[4] 1971-2000 Environment Canada Long Term Average (LTA) calculated using weather records for 1971-2000. Kitimat LTA data is for Fire Hall Weather Station ("Kitimat Townsite"). Source: Climate Data Services, Environment Canada.

[5] 1981-2010 Environmental Canada LTA calculated using weather records from 1981-2010 for Chatham Point (85.6 km from Bute; $91.2 \mathrm{~km}$ from Knight; $67.8 \mathrm{~km}$ from Toba). Source: Climate Data Services, Environment Canada.

[6] 1981-2010 Environmental Canada LTA calculated using weather records from 1981-2010 Squamish Upper. Source: Climate Data Services, Environment Canada.[7] 1988-1992 Average range between May-October (https://wateroffice.ec.gc.ca). Measurements are instantaneous suspended sediment averaged over the watercolumn depth and measured manually using a D49 sampler.

[8] Syvitski and Miliman (2007).

[9] Average from June-August calculated over 3 years (1982-1984) (https://wateroffice.ec.gc.ca). Measurements are instantaneous suspended sediment averaged over the watercolumn depth and measured manually using a P61 sampler.

[10] Hughes Clarke et al., (2014).

[11] Reading and Collinson (1996).

[12] Syvitski et al., (1988).

[13] Hickin (1989).

[14] Percentage of daily discharge values that exceed mean annual discharge value. Daily discharge values taken from Environment Canada [1].

[15] Mean discharge in excess of mean annual discharge value.

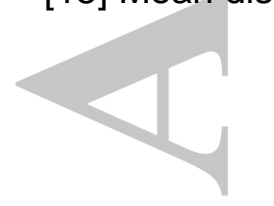


Table 2. Submarine channel morphometric parameters

\begin{tabular}{|c|c|c|c|c|}
\hline $\begin{array}{l}\text { Morphometric } \\
\text { parameter }\end{array}$ & $\begin{array}{l}\text { Squamish } \\
\text { Delta }\end{array}$ & $\begin{array}{l}\text { Toba } \\
\text { Delta }\end{array}$ & $\begin{array}{l}\text { Bute } \\
\text { Delta }\end{array}$ & $\begin{array}{l}\text { Knight } \\
\text { Delta }\end{array}$ \\
\hline Gradient $^{1 T}$ & 2 & 1.8 & 1.4 & 1.4 \\
\hline Delta-front channels & 5 & 2 & 4 & $>5$ \\
\hline Main channel length $(\mathrm{km})$ & 6.74 & 21.2 & 41.5 & 40.7 \\
\hline Main channel width ${ }^{1}(\mathrm{~m})$ & 230 & 201 & 287.2 & 236 \\
\hline Main channel relief ${ }^{1}(\mathrm{~m})$ & 12 & 12 & 19 & 20 \\
\hline Main channel sinuosity & 1.07 & 1.22 & 1.38 & 1.76 \\
\hline Terraces (km cover) & 0 & 4.5 & 12.9 & 16 \\
\hline Headless channels & 4 & 5 & 8 & 8 \\
\hline
\end{tabular}

For Kitimat Arm, all categories are zero. 

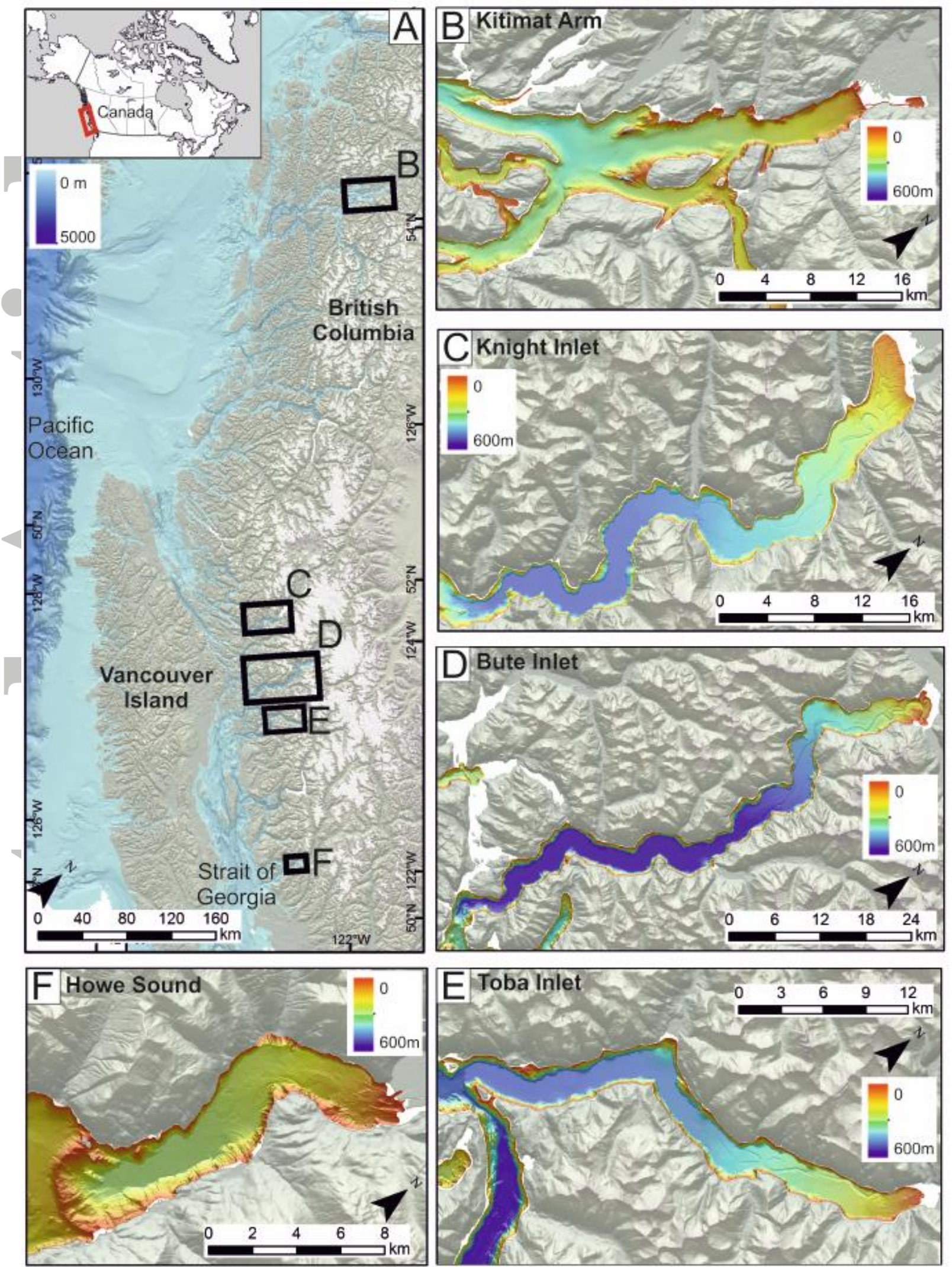

Fig. 1. A. Study area. Boxes locate (B-F). Bathymetric data is gridded at $75 \mathrm{~m}$; Topographic data is gridded at $30 \mathrm{~m}$. White shaded area is modern extent of 
icefields and glaciers. Inset figure shows location of (A). B. Bathymetric map of Kitimat Arm. $2 \mathrm{~m}$ cell size. C. Bathymetric map of Knight Inlet. $2 \mathrm{~m}$ cell size. D. Bathymetric map of Bute Inlet. $2 \mathrm{~m}$ cell size. E. Bathymetric map of Toba Inlet. $2 \mathrm{~m}$ cell size. F. Bathymetric map of Howe Sound. 2 m cell size.
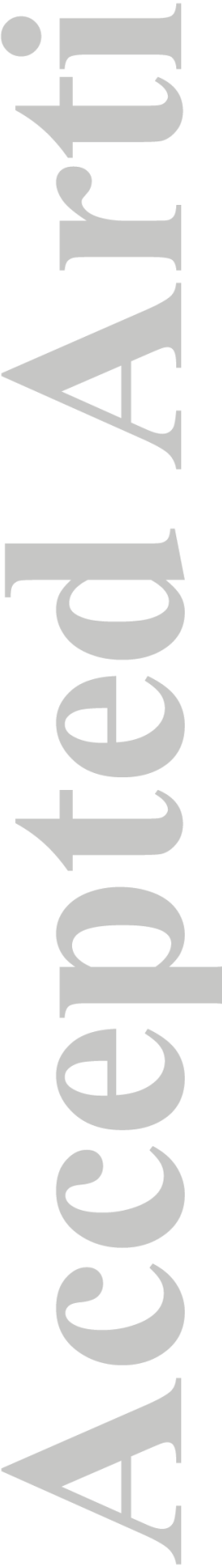


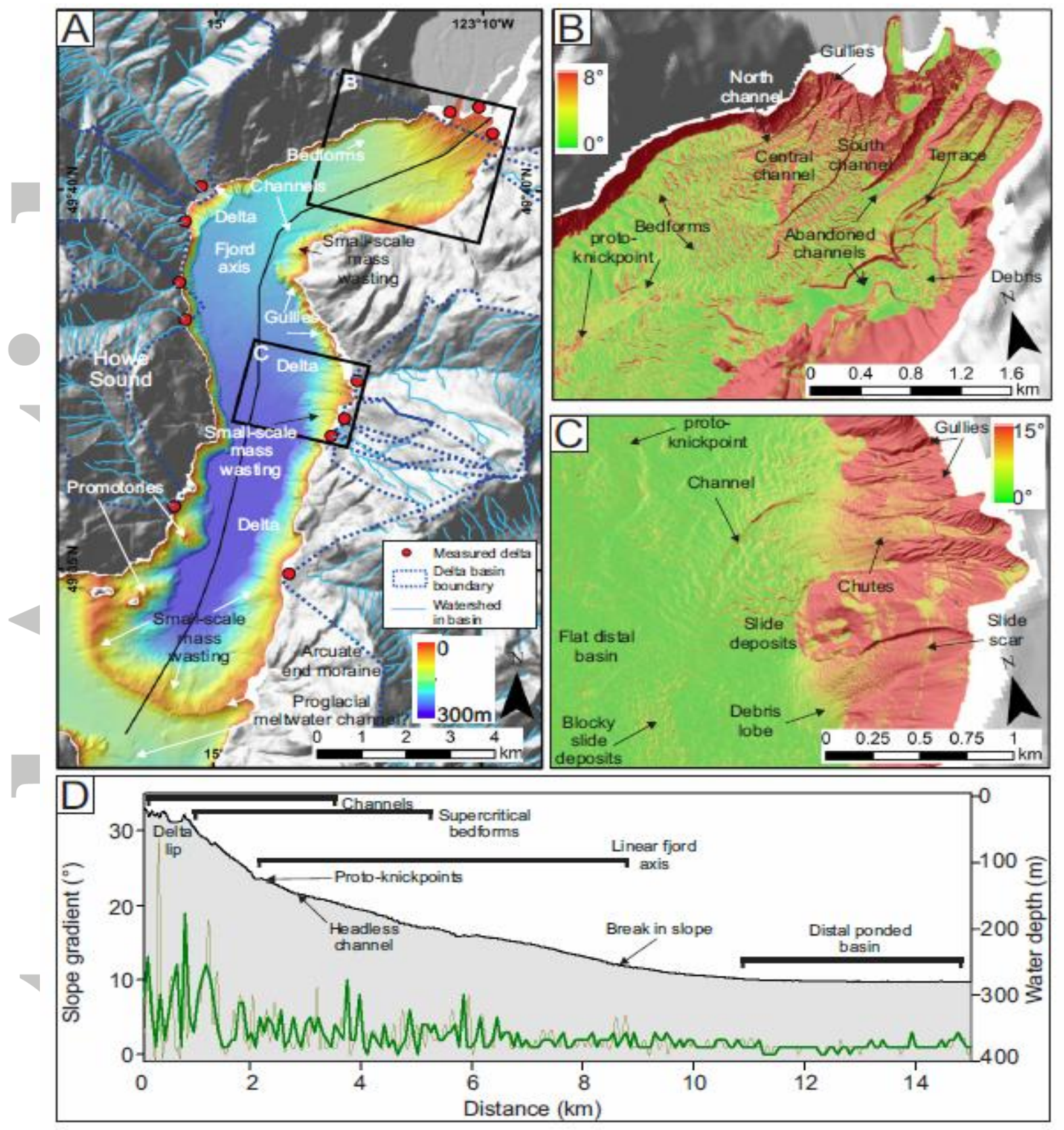

Fig. 2. A. Morphology of Howe Sound. Black line is fjord long-axis profile in (D). Red circles are deltas used in quantitative analysis. Blue dashed lines are individual river basin areas used in analysis. Light blue lines are individual delta watersheds used in analysis. B. Slope map of head of fjord (inset figure in A). C. Slope map of deltas on fjord flank (inset figure in A). D. Fjord axis long-profiles (black). Dark green line is fjord axis gradient (subsampled by 15). Light green line is smoothed gradient plot. Locations are marked in A. 


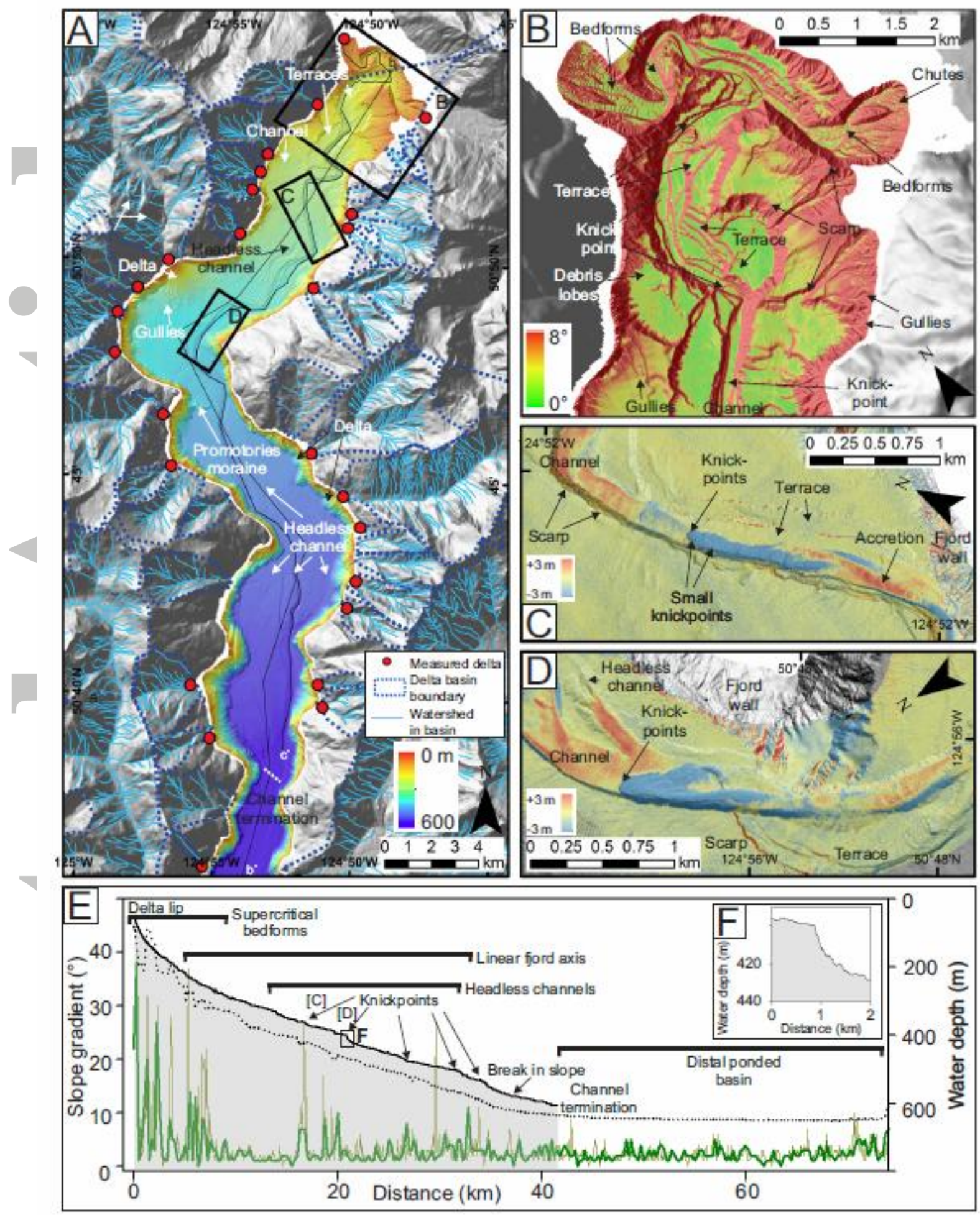

Fig. 3. A. Morphology of Bute Inlet. Black lines are fjord long-axis profile and channel axis profile in (E). Red circles are deltas used in quantitative analysis. Blue dashed lines are individual delta basin areas used in analysis. Light blue lines are 
individual delta watersheds used in analysis. B. Slope map of head of fjord (inset figure in A). C. Difference bathymetric map of data collected in 2008 and 2010 showing knickpoint within channel (inset figure in A). D. Difference bathymetric map of data collected in 2008 and 2010 showing knickpoint within channel (inset figure in A). E. Fjord axis long-profiles (black dashed line) and channel long-profile (black solid line). Dark green line is fjord axis gradient (subsampled by 50). Light green line is smoothed gradient plot. Locations are marked in A. F. Inset figure of single knickpoint marked in part E.

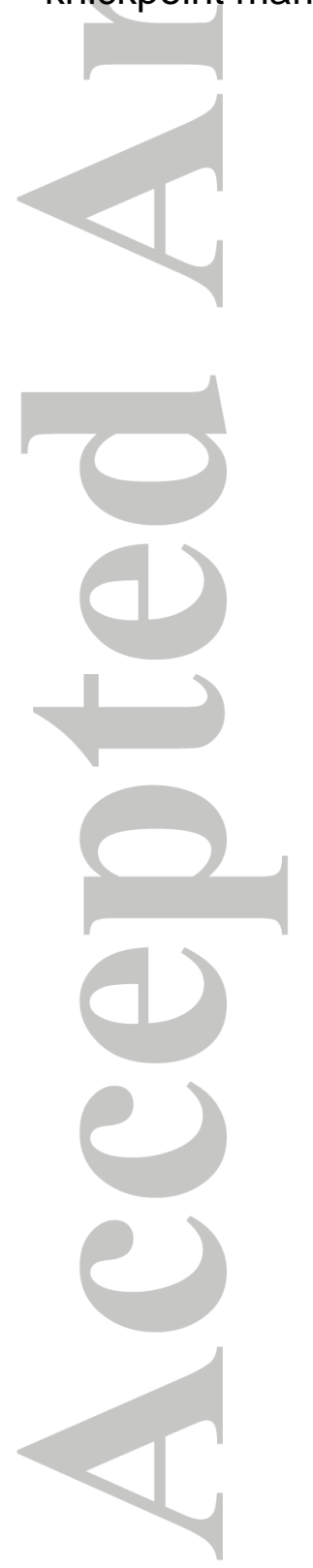



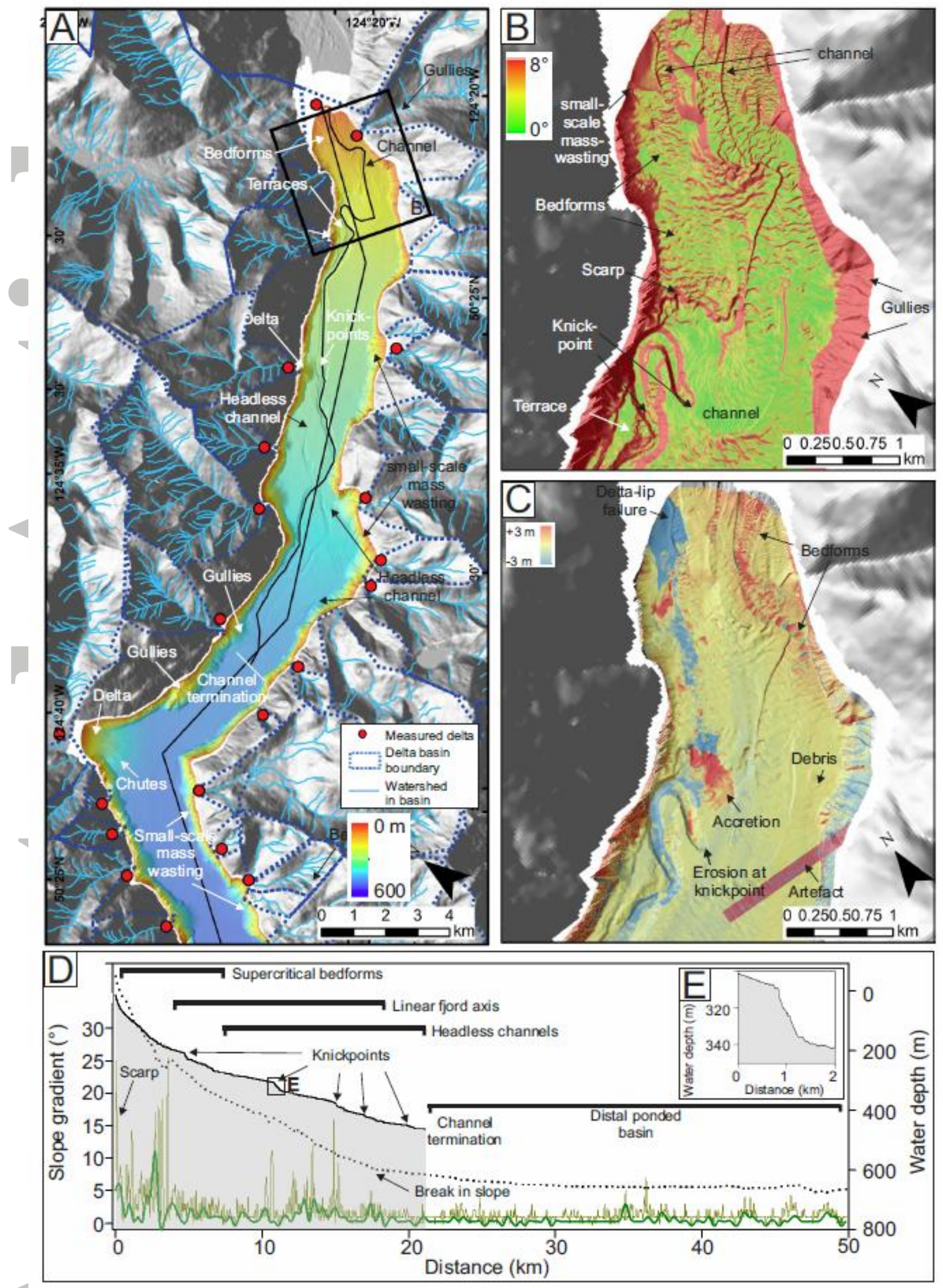

4 
Fig. 4. A. Morphology of Toba Inlet. Black lines are fjord long-axis profile and channel axis profile in (D). Red circles are deltas used in quantitative analysis. Blue dashed lines are individual delta basin areas used in analysis. Light blue lines are individual delta watersheds used in analysis. B. Slope map of head of fjord (inset figure in A). C. Difference bathymetric map of data collected in 2010 and 2008 of the delta head and channel (inset figure in A). D. Fjord axis long-profiles (black dashed line) and channel long-profile (black solid line). Dark green line is fjord axis gradient. Light green line is smoothed gradient plot. Locations are marked in A. E. Inset figure of single knickpoint marked in part D.

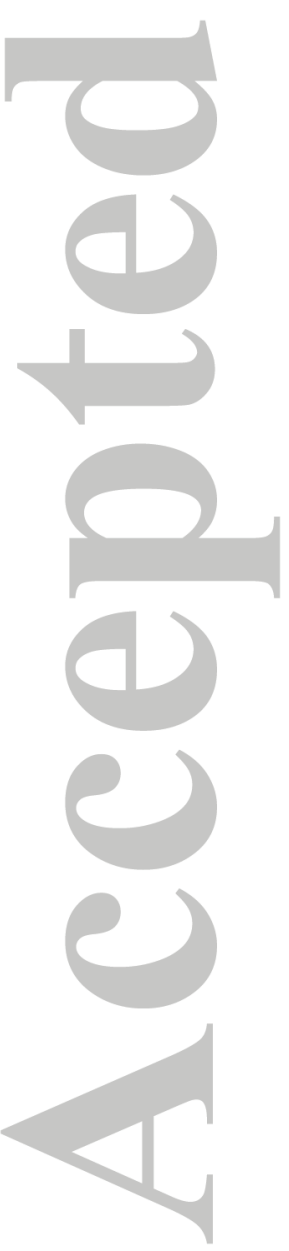




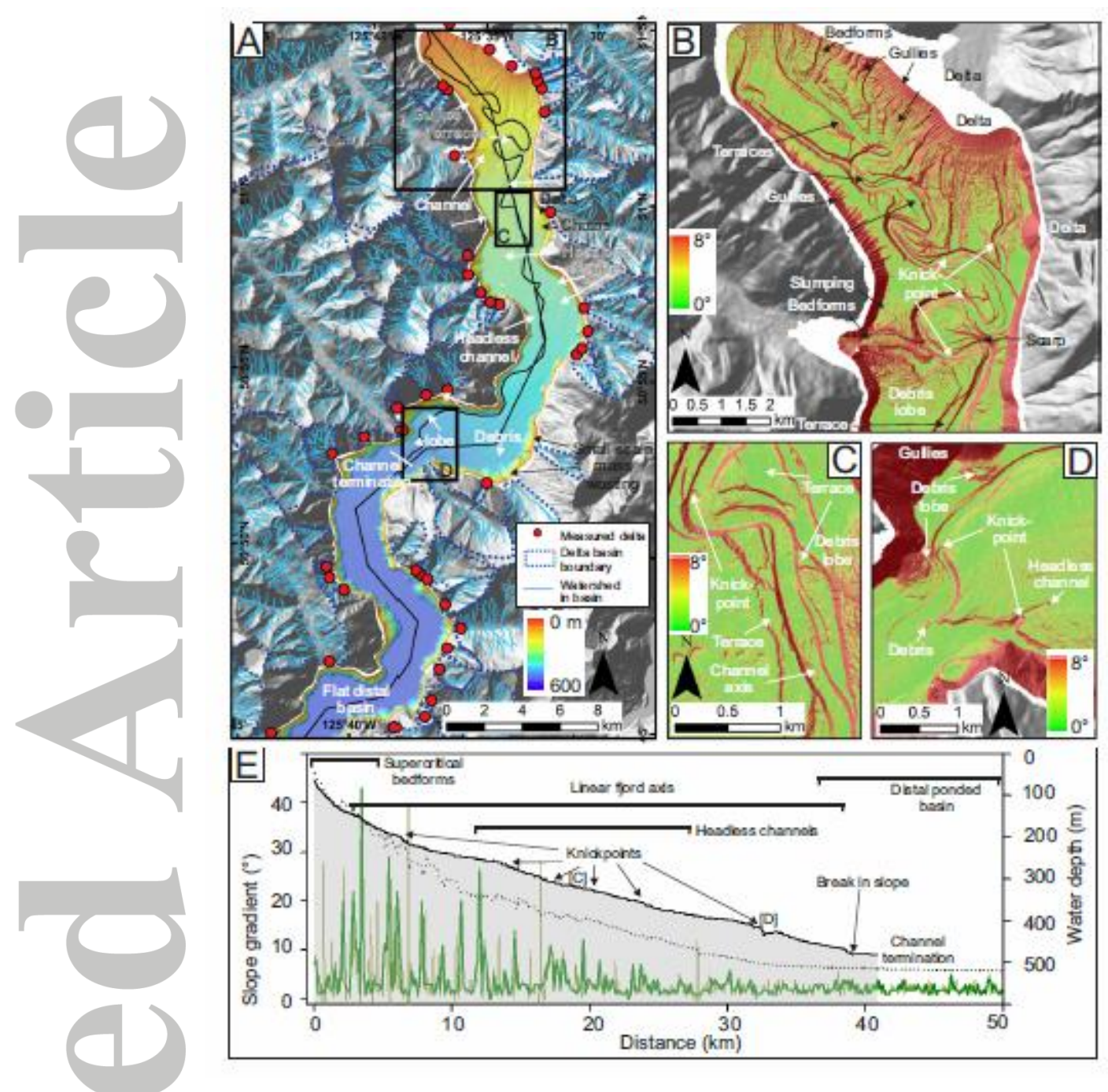

Fig 5. A. Morphology of Knight Inlet. Black lines are fjord long-axis profile and channel axis profile in (E). Red circles are deltas used in quantitative analysis. Blue dashed lines are individual delta basin areas used in analysis. Light blue lines are individual delta watersheds used in analysis. B. Slope map of head of fjord (inset figure in A). C. Slope map of knickpoint within channel (inset figure in A). D. Slope map of knickpoint within channel (inset figure in A). E. Fjord axis long-profiles (black dashed line) and channel long-profile (black solid line). Dark green line is fjord axis gradient (subsampled by 40). Light green line is smoothed gradient plot (Subsampled by 15). Locations are marked in A. 

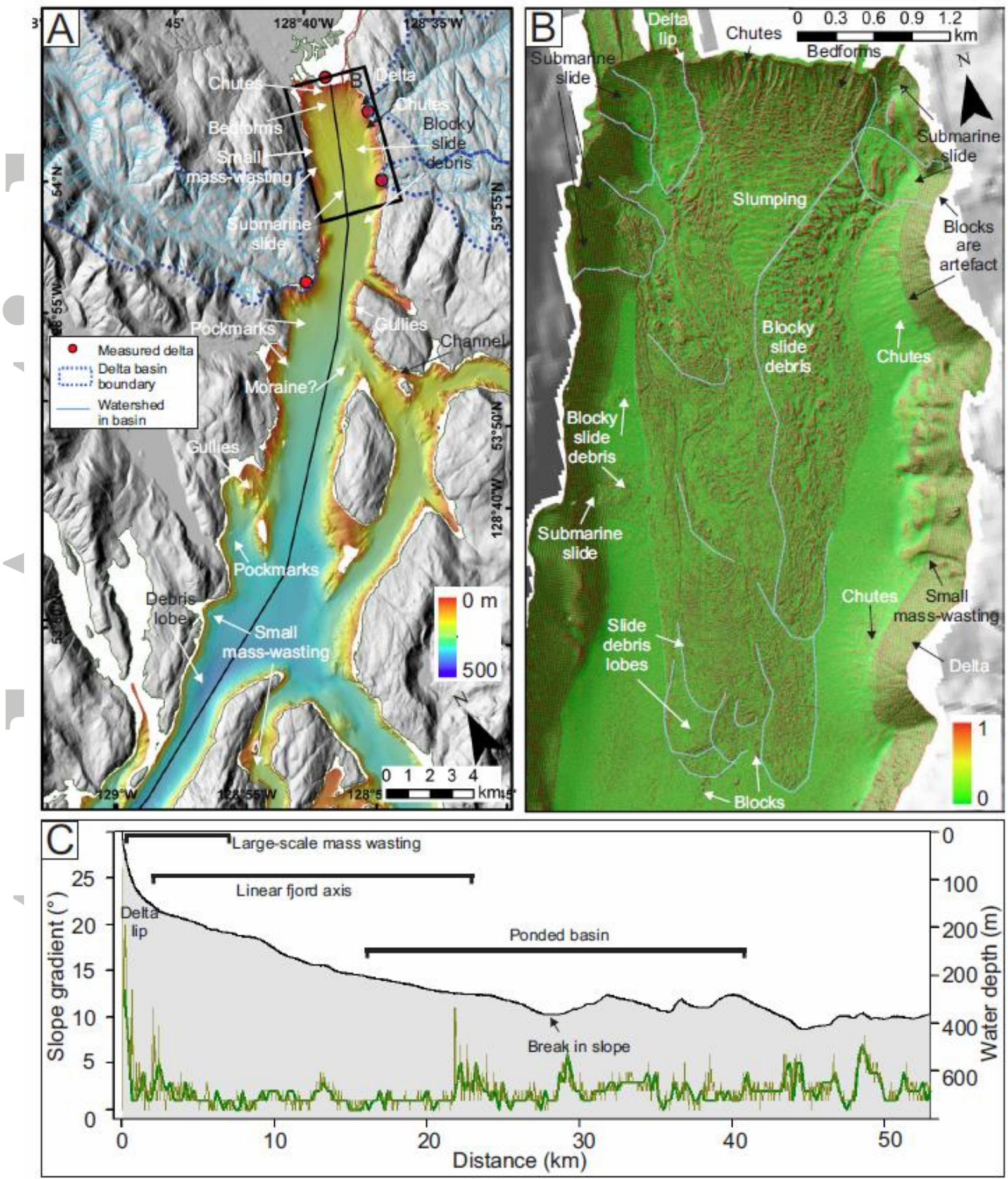

Fig. 6. A. Morphology of Kitimat Arm. Black line is fjord long-axis profile in (C). Red circles are deltas used in quantitative analysis. Blue dashed lines are individual delta basin areas used in analysis. Light blue lines are individual delta watersheds used in analysis. B. Slope map of head of fjord (inset figure in A). C. Fjord axis long-profiles 
(black solid line). Dark green line is fjord axis gradient. Light green line is smoothed gradient plot. Locations are marked in A.

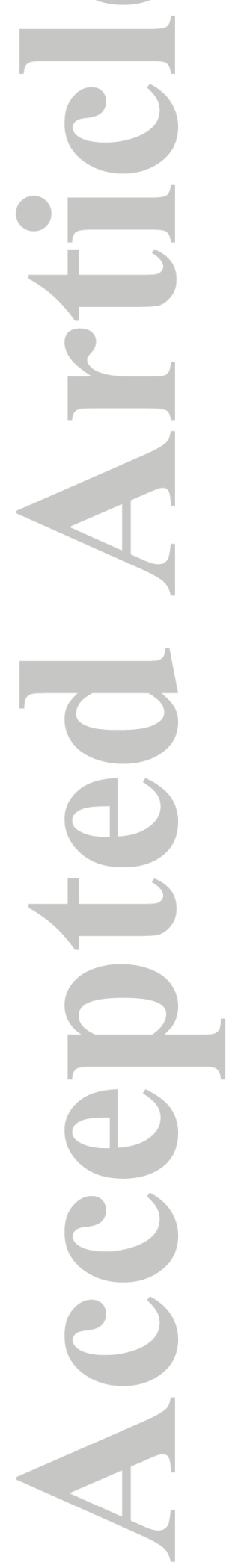



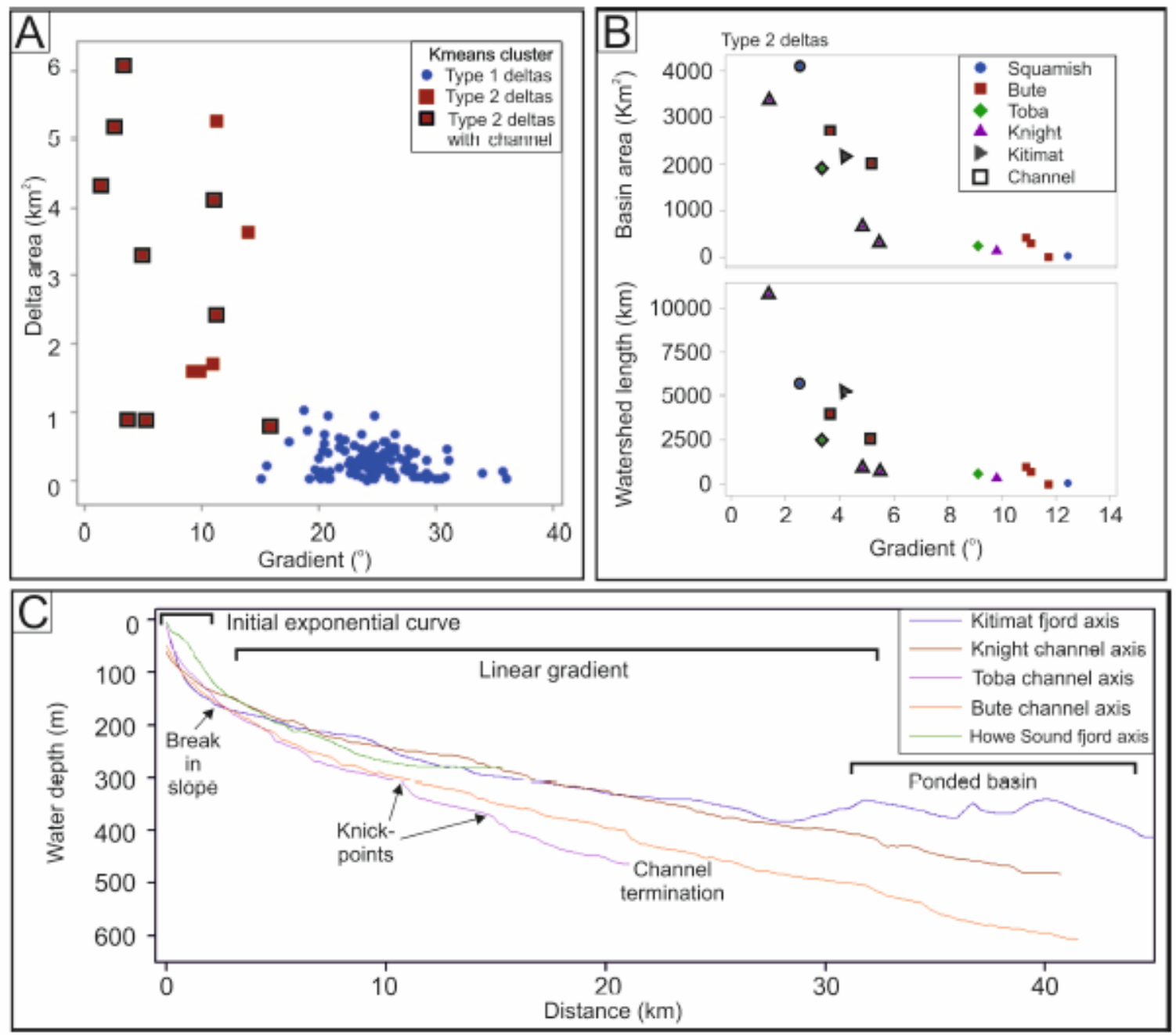

Fig. 7. A. K-means analysis for 137 deltas (type 1 and type 2). Black symbol outline indicates channel is present on delta. B. Basin area and watershed length vs slope gradient for type 2 deltas. Deltas colour coded by fjord name. Black outline indicates channel is present. C. Fjord and channel long-profiles. 

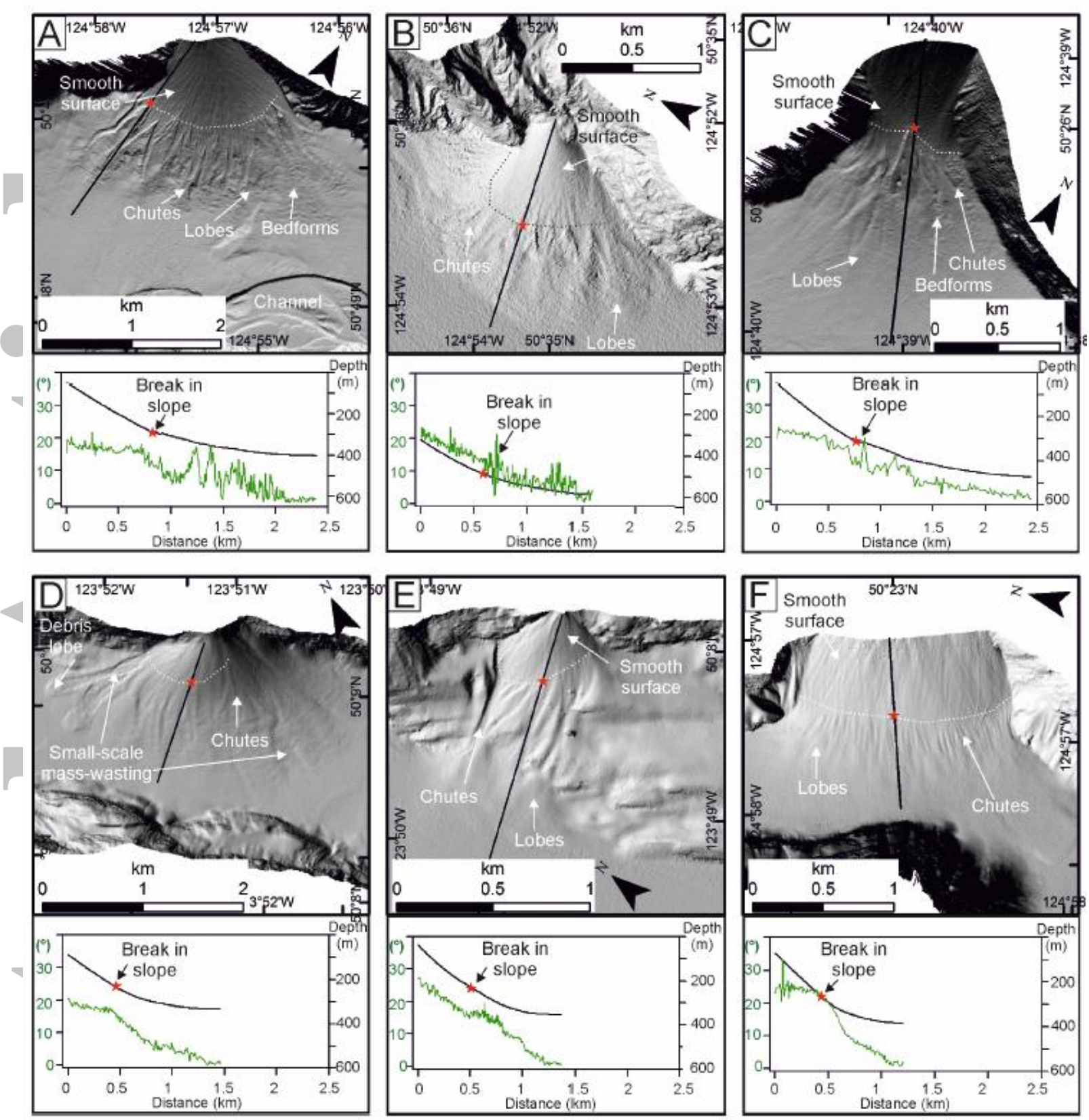

Fig. 8. Morphology of type $1 \mathrm{~b}$ submarine deltas. A, B, C, D, E and F are hillshaded bathymetric data with a cell size of $2 \mathrm{~m}$. Black lines are delta long-profiles shown in inset figure below (for both long-profile and gradient). Inset figures: black line is delta long-profile. Green line is delta gradient profile. Red star marks same position on image and graph indicating break in slope (dashed line). 


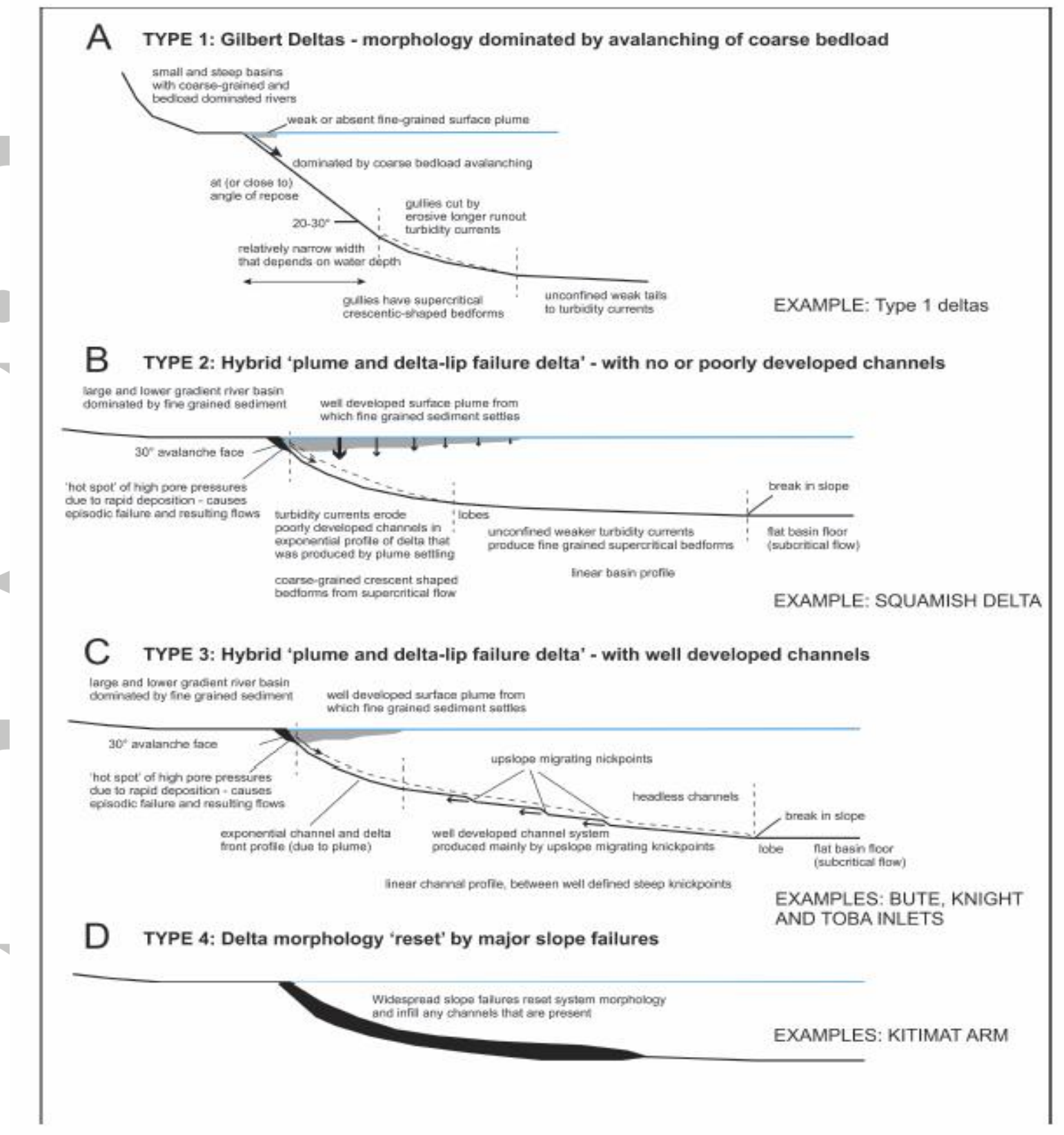

Fig. 9. Schematic figure showing four types of turbidity current and delta system, for relatively deep offshore settings. A. Small-scale, high-gradient and low area 'Gilbert' deltas dominated by avalanching of coarse bedload. B. Hybrid surface plume and delta-lip failure deltas with no or poorly developed channels. C. Hybrid surface plume and delta-lip failure deltas with extensive channels. D. Delta morphologies that are reset by widespread slope failure. 